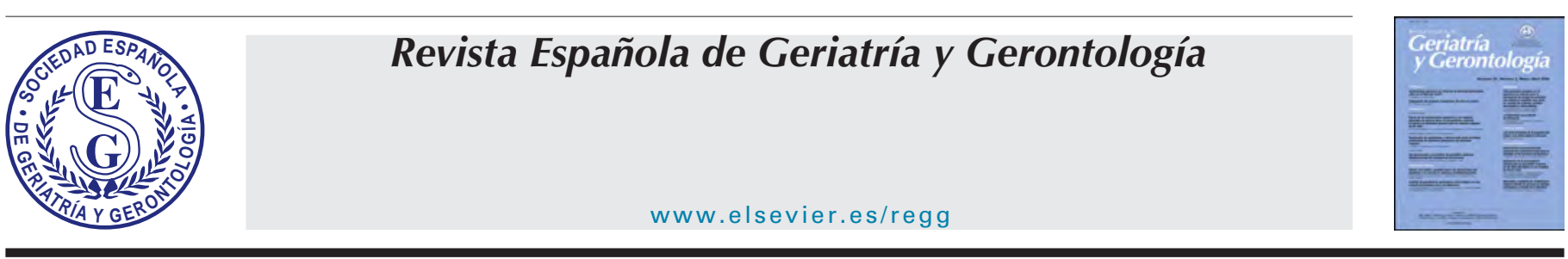

REVIEW

\title{
Efficacy, cost, and aspects to take into account in the treatment of osteoporosis in the elderly
}

\author{
Pilar Sáez-López a,f,*, Iñigo Etxebarria-Foronda ${ }^{\mathrm{b}}$, Maria Pilar Mesa Lampre ${ }^{\mathrm{c}}$, Noelia Alonso García ${ }^{\mathrm{d}}$, \\ Natalia Sánchez Hernández ${ }^{\mathrm{e}}$ \\ a Geriatrics Department, Hospital Universitario Fundación Alcorcón, Madrid, Spain \\ b Traumatology Department, Hospital Alto Deba, Gipuzkoa, Spain \\ c Geriatrics Department, Hospital Ntra Sra de Gracia, Zaragoza, Spain \\ d Traumatology Department, Complejo Asistencial de Segovia, Segovia, Spain \\ e Traumatology Department, Complejo Asistencial de Ávila, Ávila, Spain \\ ${ }^{\mathrm{f}}$ Instituto de Investigación del Hospital La Paz IdiPAZ, Madrid, Spain
}

\section{A R T I C L E I N F O}

\section{Article history:}

Received 23 June 2018

Accepted 26 November 2018

Available online $\mathrm{xxx}$

\section{Keywords:}

Elderly

Osteoporosis treatment

Efficacy

\begin{abstract}
A B S T R A C T
Age is one of the principal risk factors for development of frailty fractures. Age pyramids show a population that is becoming increasingly more elderly, with an increasing incidence of fractures, and the forecasts for the future are truly alarming. Adequate handling of these patients who are especially at risk, at both the preventive and care levels, with a well-defined orthogeriatric model is necessary to respond to this clinical challenge. The objective of this review is to analyze the efficacy of the different strategies for the handling of geriatric patients with fracture risk.
\end{abstract}

(c) 2018 SEGG. Published by Elsevier España, S.L.U. All rights reserved.

\section{Eficacia, coste y aspectos a tener en cuenta sobre el tratamiento de la osteoporosis en el anciano}

\section{R E S U M E N}

La edad es uno de los principales factores de riesgo para desarrollar una fractura por fragilidad. Las pirámides de edad muestran una población cada vez más envejecida y la incidencia de fracturas es cada vez mayor, siendo las previsiones para el futuro verdaderamente preocupantes. Un adecuado manejo de estos pacientes de especial riesgo, tanto a nivel preventivo como asistencial con un modelo ortogeriátrico bien definido se hacen necesarias para hacer frente a este reto clínico. En esta revisión queremos realizar un análisis de la eficacia de las diferentes estrategias de manejo del paciente geriátrico con riesgo de fractura.

(C) 2018 SEGG. Publicado por Elsevier España, S.L.U. Todos los derechos reservados.

\section{Introduction: why consider treatment of osteoporosis in the elderly}

As the age of the population increases, the incidence of osteoporosis and its direct consequence, fragility fractures, are also increasing. ${ }^{1}$ The presence of a fragility fracture multiplies the risk

\footnotetext{
* Corresponding author.

E-mail address: pisalop@gmail.com (P. Sáez-López).
}

of a second fracture by three, which in turn multiplies the risk of a third fracture by five, and of a fourth by eight ${ }^{2}$. It has been calculated that in the first year following a fracture, between $9 \%$ and $14 \%$ of patients will suffer another, despite the competing risk of increased mortality associated with them. ${ }^{2,3}$ The increased mortality related to osteoporotic fractures varies with location, advanced age, and the time elapsed following the fracture. ${ }^{4-6}$

Hip fractures are associated with the greatest number of complications, functional deterioration, need for more assistance, and mortality of up to $30 \%$ one year after the fracture. ${ }^{7-10}$ This 
problem also represents a significant expense for healthcare systems, surpassing even the cost of other frequent pathologies such as diabetes. ${ }^{11-13}$

Numerous drugs have shown an improvement in regard to parameters of bone mineral density, reduction of fractures, and mortality in patients with osteoporosis. ${ }^{4,14-17}$ Decisions by the administration, guidelines of scientific societies, and prices of the treatments themselves are variables that can influence both the increased detection and treatment of the problem as well as its repercussions in terms of the incidence of fractures. Consequently, the publication of the 2005 NICE Guidelines on the secondary prevention of fractures, along with the commercialization of the generic of alendronate, encouraged an increase in the prescription of the drug, with a reduction in major fractures and hip fractures later observed in the United Kingdom. ${ }^{18}$ On the other hand, in the US, the reduction in the reimbursement for densitometry in 2007 resulted in a decrease in the diagnosis of osteoporosis in the years that followed and halted the downward evolution of the incidence of hip fractures that had been observed since the year $2000 .^{19}$

We are therefore dealing with a pathology that is very prevalent in the elderly, incapacitating, that reduces survival to a large degree, that involves a high cost for the care of the direct consequences, which are fractures, and for which treatments exist that can reduce its incidence. These reasons are sufficient to treat this process.

This article reviews the efficacy and cost-effectiveness of treatment of osteoporosis in the elderly, as well as its effect on mortality and aspects to be taken into account before initiating prescription of the treatment.

\section{Efficacy of anti-osteoporotic drugs in the elderly and cost-effectiveness}

\section{Calcium and vitamin $D$}

At least three meta-analyses have shown that treatment with calcium and vitamin $D$ reduce the incidence of fractures, ${ }^{20-22}$ by percentages that range from $6 \%$ to $23 \%$ in the reduction of nonvertebral fractures and $16-30 \%$ for hip fractures. Several other studies have found a relationship between low vitamin D levels and increased incidence of osteoporotic fractures. ${ }^{23-25}$

Nevertheless, a recent meta-analysis did not find decreased risk of fracture in patients of the community treated with calcium and/or vitamin $\mathrm{D}$, although the age criterion for inclusion was older than 50 years of age, so patients were not overwhelmingly those with greater risk of fractures. ${ }^{26}$ Hiligsman showed that this treatment is cost-effective in women over the age of 60 diagnosed with osteoporosis, but it is much more effective to treat women over the age of 80 with this diagnosis. ${ }^{27}$

Although some publications have suggested that calcium supplementation could be associated with increased cardiovascular risk, ${ }^{28,29}$ recently doubts have arising regarding defects in the methodology that condition the validity of the results of these studies $^{30}$ and therefore the NOF (National Osteoporosis Foundation) as well as the ASPC (American Society for Preventive Cardiology) have published that there is no evidence demonstrating cardiovascular problems at calcium doses between 2000 and $2500 \mathrm{mg} /$ day. $^{31}$

According to the recent Clinical Practice Guidelines (CPG) of the American College of Physicians with a moderate degree of evidence, that the efficacy of calcium and vitamin $\mathrm{D}$ in the reduction of fractures is uncertain. ${ }^{17}$

\section{Biphosphonates}

According to most of the Clinical Guidelines, biphosphonates are considered to be first-line drugs in the treatment of osteoporosis due to their low cost and long-term safety, making them the most cost-effective, especially the generics alendronate and zoledronate. ${ }^{32}$

\section{Efficacy}

This group of drugs can reduce the incidence of osteoporotic fractures, both vertebral and non-vertebral, and hip fractures. ${ }^{33,34}$ The cumulative benefit in the reduction of fractures over 3 years varies between an RR of 0.3 and 1 . However, not all have shown the same efficacy. ${ }^{14}$ In a recent meta-analysis of 39,197 patients $^{34}$ the evidence of the efficacy of biphosphonates in reducing osteoporotic fractures was updated. In this case, zoledronic acid was once again found to be the most effective, with an OR 0.61 (0.49-0.76) in comparison with alendronate OR $0.64(0.48-0.84)$ or risedronate OR $0.74(0.63-0.85)$.

Most pivotal studies have been done on patients younger than 80 years of age, but in recent years sub-analysis results in the elderly population have become available. Hochberg, ${ }^{35}$ showed that alendronate reduces the incidence of the most prevalent fractures. They found a reduction in the absolute risk of the set of vertebral, wrist, and hip fracture, and that effect increased with age; in other words, it is more effective in patients between 75 and 85 years of age because they are the population with the highest risk. A post hoc analysis of data from the largest alendronate study (Fracture Intervention Trial, FIT) of an elderly population with non-vertebral fracture, suggested, without achieving statistical significance, that alendronate was less effective in reducing fractures in women with T-scores above $-2.5 \mathrm{DE}$ than in women with osteoporosis. ${ }^{36}$ Boonen $^{37}$ carried out a post hoc analysis in women over the age of 80 , combining 3 large randomized doubleblind clinical trials with risedronate (HIP, VERT-NA and VERT-MN). It showed that in the first year, the reduction of vertebral fractures with risedronate was $81 \%$, with similar results in subjects older and younger than 80 years of age, finding no effect on hip fractures. The number of patients needed to treat (NNT) for one year to avoid a vertebral fracture is 12 . The same author ${ }^{38}$ did a post hoc of the Horizon comparing annual zoledronic acid with a placebo in women over the age of 75 with 3-year follow-up and it showed a reduction in vertebral and non-vertebral fractures with a hazard ratio of 0.34 and 0.73 , respectively. As with the previous work, it did not manage to demonstrate a reduction in hip fractures, attributing this to the multiple extra-skeletal factors that favour this type of fracture. Also, Nordström, ${ }^{39}$ in a study on 93,601 patients, showed that the reduction in the risk of fracture after treatment with bisphosphonate is similar in patients over the age of 80 with regard to younger patients (25\% lower risk of another hip fracture after a previous fracture). Another detail shows a meta-analysis, meta-regression of 13 studies on the efficacy of antiresorptive drugs in elderly subjects from 70-80 years of age, finding that the reduction in the risk of vertebral fracture increases with age, with body mass index, and duration of the treatment, although once again, this effect was not observed in hip fractures. ${ }^{40}$ In 6 of the studies, the average age was over 70, although just two studies were aimed at elderly women: TROPOS (74 y) and HIP (70-79 and >80y).

\section{Efficiency}

There are several experiences that show that treatment with biphosphonates in the elderly is equally or more cost effective than at other ages because they are the population with the highest risk of fracture. Many of the studies used the Markov model, which was created to assess the cost-effectiveness of the treatment of patients with osteoporosis in different countries. It represents the possible health transitions from the start of treatment, such as: prevention of fractures up to 100 years of age, including fractures of the radius, vertebra, hip, other osteoporotic fractures, fracture after vertebral fracture, fracture after hip fracture, and death. In 6-month cycles, 
patients could remain healthy, suffer fractures, or death. Nayak ${ }^{41}$ used a simulation to study the cost of performing screening using DXA and treatment with alendronate if the result was compatible with osteoporosis in women over the age of 65. They compared it with treatment only after a fragility fracture. The simulation assessed the cost of the screening, of the treatment, of the adverse effects and mortality, of the repercussion on admittance to residences, of the quality-adjusted life years (QALY) and of the increase in cost-effectiveness ratios (ICERs). They found, assuming a cost of alendronate between 400 and 800 dollars per year, that screening and pertinent treatment is highly cost effective, but if the cost of alendronate drops to $200 \$$ per year, the screening and treatment decision is much more inexpensive than treating the consequences of osteoporosis. A similar study done in China ${ }^{42}$ showed that treatment of osteoporosis in women over the age of 75 is more cost effective than in younger women, varying the ratio with the treatment threshold and the cost of the treatment in China. They found that treatment in elderly patients with more than a $3 \%$ risk of suffering hip fracture within 10 years is cost effective, while other authors increase that risk to $6.5 \%$ to achieve cost-effectiveness in males of the same age. ${ }^{43}$

Tjeerd-Peter van Staa ${ }^{44}$ published the first economic model in the field of osteoporosis applying individual fracture and mortality risks. Treatment with biphosphonates was cost-effective in patients with a 5-year risk of osteoporotic fracture of $9.3 \%$. It was effective provided that bone mineral density (BMD) was low, and was less effective if BMD was normal. In 2005, Kanis ${ }^{45}$ published models in which treatment with biphosphonates was cost-effective. Therefore, a drug that reduces fractures by $35 \%$ and at an annual cost of $500 \$$ would be cost-effective if the 10 -year probability of hip fracture was $1.2 \%$ in women 50 years of age and $7.2 \%$ in women 85 years of age. This study found that younger patients with several clinical risk factors had fracture risk and mortality comparable to older patients without risk factors and those patients had similar intervention thresholds when clinical risk factors were taken into account. It was found that treatment with biphosphonates reduced costs in almost all women older than 80 years of age and in patients with low body mass index (BMI). They observed that the avoided costs resulting from the prevented fractures exceeded the cost of the intervention.

Tables 1-3 show studies on the cost-efficiency of biphosphonates (alendronate, risedronate, and zoledronic acid) that showed efficacy in reducing vertebral fractures (VF), non-vertebral fractures (NVF) and hip fractures (HF).

\section{Denosumab}

This is an antiresorptive monoclonal antibody drug that inhibits the formation, activation, and survival of osteoclasts by blocking the RANK/RANKL/OPG system. There are publications that show that Denosumab increases BMD more than biphosphonates ${ }^{66}$ and this increase was found to be continuous and almost linear, from the 3rd to the 8th year of treatment. As with other antiresorptives decreases cortical porosity and also provides a certain degree of remodelling with an increase in cortical thickness and strength. ${ }^{67}$ On the other hand, the increased BMD gained during the first two years of treatment with denosumab, has been observed to be lost during the first year after abandonment of the treatment ${ }^{68}$ and an increase in vertebral fractures was observed after withdrawal, so it is recommended that the treatment be continued with another drug to maintain the BMD.

\section{Efficacy}

In regard to data on efficacy in elderly patients, this drug reduced vertebral fractures, non-vertebral fractures, and hip fractures in both patients over and under 75 years of age, with similar BMD increases, and without changes in terms of side effects in both age groups. ${ }^{69}$ After 3 years of treatment, a reduction in the risk of new radiological vertebral fractures of $68 \%$ was achieved, and a reduction of $40 \%$ for hip fractures, and $20 \%$ for non-vertebral fractures. ${ }^{70}$ The absolute reduction of fractures was $4.8 \%, 0.3 \%$, and $1.5 \%$ for new vertebral fractures, hip fractures, and non-vertebral fractures, respectively. A post hoc study showed a significant reduction in new vertebral and hip fractures in women over 75 , as well as in the sub-groups of women with fracture risk. ${ }^{71,72}$ In the long-term treatment group of the phase 3 randomized study of the FREEDOM (extension study from year 3 to 10), the annualized incidence of patients with new vertebral fractures, non-vertebral fractures, and hip fractures during the extension phase remained at levels similar to the incidence observed during the FREEDOM study (first three years). The cumulative incidence of new vertebral fractures and non-vertebral fractures in the extension phase was lower than the estimated incidence for the virtual twin placebo group. ${ }^{73}$

\section{Efficiency}

In regard to cost-effectiveness, which is also evaluated frequently using the Markov model, there are several publications with a series of favourable results in terms of efficacy for denosumab (Table 4). In these studies, the good results for Denosumab in terms of cost-effectiveness are attributed to the persistence and improved efficacy of this drug. ${ }^{74}$ In a recent review of the subject, denosumab was found to be more cost effective in the elderly, patients with a history of fractures, and with lower BMD. ${ }^{75}$

\section{Teriparatide}

Teriparatide or PTH 1-34 (amino-terminal recombinant fragment of the parathyroid hormone) is currently the only one of the available drugs considered to be an anabolic steroid, due to its capacity to stimulate bone formation. Conceptually, and taking into account that age is one of the main risk factors for the development of bone fragility, it could be a good option for increasing bone strength in elderly patients with a marked structural alteration of the bone at both the cortical and trabecular levels.

\section{Efficacy}

In the reference or pivotal trial of the drug, ${ }^{80}$ the Fracture Prevention Trial (FPT), which analyzed the effect of the drug in comparison with a placebo in 1637 post-menopausal women with at least one vertebral fracture and with an average follow-up of 21 months, a significant reduction was found in the rate of new vertebral fractures (65 and 69\%, respectively) and non-vertebral fractures (53 and 54\%). In addition, the risk of multiple vertebral fractures (77 and $86 \%$ ) and fractures considered moderate or severe (90 and 78\%) was also lower. A favourable effect in the increase in BMD in the lumbar column (9.7\% and $13.7 \%$ ) and in the femoral neck (2.8\% and 5.1\%) was also noted. But the average age of these patients was 69. It is known that the average age of the patients in studies to determine the efficacy of drugs for osteoporosis is 64 , while the average age of the patients who suffer hip fractures is $84 .{ }^{81}$ In this reference study, an initial screening of 9347 women was done, followed by a sub-analysis with the patients of the FPT, comparing patients younger and older than 75 years of age. ${ }^{82}$ Remodelling markers, BMD, fracture risk, and adverse effects were evaluated, with similar results, especially in regard to the reduction in new vertebral fractures, with an NNT (number needed to treat) of 11 in both groups, concluding that age does not affect the safety and efficacy of the drug, making it a valid alternative in this type of patient. Similar results were obtained in other sub-analyses of the same cohort of patients. ${ }^{83}$ 
Table 1

Cost-effectiveness of alendronate.

\begin{tabular}{|c|c|c|c|}
\hline Author/country & Study population & Drug & Results \\
\hline $\begin{array}{l}\text { Jansen et al. }{ }^{46}(2008) \\
\text { United Kingdom and } \\
\text { the Netherlands }\end{array}$ & $\begin{array}{l}\text { Women }>50 \text { years of age with history } \\
\text { of vertebral Fx and OP }\end{array}$ & $\begin{array}{l}\text { Alendronate/vit D vs no } \\
\text { treatment and vs } \\
\text { alendronate + vitD dietary } \\
\text { supplements }\end{array}$ & $\begin{array}{l}\text { Alendronate/vit } D \text { was cost-effective vs no treatment in } \geq 70 \mathrm{y} \text {. } \\
(17,439 £ \text { per QALY gained) and reduced costs in comparison with } \\
\text { alendronate with dietary supplements. }\end{array}$ \\
\hline $\begin{array}{l}\text { Kanis et al. }{ }^{47}(2008) \\
\text { United Kingdom }\end{array}$ & $\begin{array}{l}\text { Women }>50 \text { years of age with different } \\
\text { risk factors }\end{array}$ & $\begin{array}{l}\text { Generic alendronate vs no } \\
\text { treatment }\end{array}$ & $\begin{array}{l}\text { Using a limit of } 30,000 £ \text { and } 20,000 £ \text { per } Q A L Y \text {, alendronate was } \\
\text { cost-effective for the prevention of primary fracture in women } \\
\text { with OP, regardless of age. }\end{array}$ \\
\hline $\begin{array}{l}\text { Kanis et al. }{ }^{48}(2008) \\
\text { United Kingdom }\end{array}$ & Women $>50$ using FRAX & $\begin{array}{l}\text { Generic alendronate versus no } \\
\text { treatment }\end{array}$ & $\begin{array}{l}\text { Using a limit of } 20,000 £ \text { per QALY gained, the treatment was } \\
\text { cost-effective at any age if the } 10 \text {-year fracture risk }>7 \% \text {. }\end{array}$ \\
\hline $\begin{array}{l}\text { Hiligsmann et al. }{ }^{49} \\
\text { (2009) } \\
\text { Netherlands }\end{array}$ & $\begin{array}{l}\text { Women }>70 \text { years of age with } 2 \text { times } \\
\text { the fracture risk of the general } \\
\text { population }\end{array}$ & Vs no treatment & $\begin{array}{l}\text { ICER de } 9105 € \text { if full adherence and } 15,325 € \text { for current } \\
\text { adherence. }\end{array}$ \\
\hline $\begin{array}{l}\text { Hiligsman et al. }{ }^{50} \\
(2010) \\
\text { Netherlands }\end{array}$ & $\begin{array}{l}\text { Women }>65 \text { years of age with } T \text {-score } \\
\text { of }-2.5\end{array}$ & $\begin{array}{l}\text { Branded biphosphonates and } \\
\text { generic alendronate vs no } \\
\text { treatment }\end{array}$ & $\begin{array}{l}\text { The costs per QALY gained for branded bisphosphonate (and } \\
\text { generic alendronate) were estimated at } 19,069 €(4871 €) \text {, } \\
32,278 €(11,985 €) \text { and } 64,052 €(30,181 €) \text { for MPR values of } 100 \text {, } \\
80 \text {, and } 60 \% \text {, respectively, assuming real adherence. Those values } \\
\text { were } 16,997 €(2215 €), 24,401 €(6179 €) \text { and } 51,750 €(20,569 \\
€) \text { assuming full adherence. }\end{array}$ \\
\hline $\begin{array}{l}\text { Hiligsmann and } \\
\text { Reginster }^{51}(2011) \\
\text { Netherlands }\end{array}$ & $\begin{array}{l}\text { Women }>60 \text { years of age with T-score } \\
\leq-2.5\end{array}$ & $\begin{array}{l}\text { Denosumab vs oral } \\
\text { biphosphonate }\end{array}$ & $\begin{array}{l}\text { Denosumab cost-effective versus branded alendronate and } \\
\text { Risedronate at a value limit of } 30,000 € \text { per QALY. Compared with } \\
\text { generic alendronate: } 38,514 €, 22,220 € \text { and } 27,862 € \text { at } 60,70 \text { and } \\
80 \text { years of age, respectively. }\end{array}$ \\
\hline $\begin{array}{l}\text { Pham et } \text { al. }^{52}(2011) \\
\text { USA }\end{array}$ & $\begin{array}{l}\text { Cohort of women with different life } \\
\text { expectancies, in treatment for OP from } \\
50 \text { to } 90 \text { years of age }\end{array}$ & BP vs no treatment & $\begin{array}{l}\text { In the healthiest group, all costs were less than } 18,000 \$ \text { per QALY. } \\
\text { In average quartiles, the costs per QALY were less than } 27,000 \$ \text { for } \\
\text { patients of all ages. There was a cost savings at } 75 \text { years of age and } \\
\text { it was maintained until age } 85 \text {. }\end{array}$ \\
\hline $\begin{array}{l}\text { Lippuner et al. }{ }^{53} \text { (2012) } \\
\text { Switzerland }\end{array}$ & $\begin{array}{l}\text { Women }>50 \text { with different fracture } \\
\text { probabilities }\end{array}$ & $\begin{array}{l}\text { Branded alendronate vs no } \\
\text { treatment }\end{array}$ & $\begin{array}{l}\text { Assuming a willingness to pay twice the gross national product per } \\
\text { person, branded alendronate was cost-effective with a } 10 \text {-year } \\
\text { osteoporotic fracture probability }>13.8 \% \text {. }\end{array}$ \\
\hline $\begin{array}{l}\text { Moriwaki et al. }{ }^{54} \\
(2013) \\
\text { Japan }\end{array}$ & $\begin{array}{l}\text { Osteopenic women }>65 \text { years of age } \\
\text { without a history of fractures }\end{array}$ & Vs no treatment & $\begin{array}{l}\text { ICER } 227,905 \$ \text { in women without risk factors, } 92,937 \$ \text { if family } \\
\text { history of hip Fx; } 126,251 \$ \text { if drink alcohol, and } 129,067 \$ \text { for } \\
\text { smokers. The cost-effectiveness of the preventive alendronate for } \\
\text { osteopenic women is sensitive to age, BMD, and number of risk } \\
\text { factors. }\end{array}$ \\
\hline $\begin{array}{l}\text { Parthan et } \text { al. }^{55}(2013) \\
\text { USA }\end{array}$ & $\begin{array}{l}\text { Post-menopausal population and } \\
\text { sub-groups }\end{array}$ & $\begin{array}{l}\text { Denosumab vs generic } \\
\text { alendronate, branded } \\
\text { risedronate and branded } \\
\text { ibandronate }\end{array}$ & $\begin{array}{l}\text { ICER of denosumab vs generic alendronate was } 70,400 \$ \text { for the } \\
\text { entire group and } 7900 \$ \text { for sub-groups. Risedronate and } \\
\text { ibandronate were dominated by denosumab. }\end{array}$ \\
\hline $\begin{array}{l}\text { Alzhaouri et al. }{ }^{56} \\
(2013) \\
\text { France }\end{array}$ & $\begin{array}{l}\text { Women }>70 \text { years of age with T-score } \\
\text { of }-2.5\end{array}$ & $\begin{array}{l}\text { Branded alendronate vs no } \\
\text { treatment }\end{array}$ & $\begin{array}{l}\text { ICER of } 104,183 \text { to } 413,473 € \text { per QALY when FRAX decreased from } \\
10 \text { to } 3 \%\end{array}$ \\
\hline
\end{tabular}

ICER: incremental cost effectiveness ratio; QALY: quality-adjusted life years; FRAX: tool that makes it possible to calculate fracture risk.

Table 2

Cost-effectiveness of risedronate.

\begin{tabular}{|c|c|c|c|}
\hline Author/country & Study population & Drug & Results \\
\hline $\begin{array}{l}\text { Wasserfallen et al. }{ }^{57} \text { (2008) } \\
\text { Switzerland }\end{array}$ & $\begin{array}{l}\text { Women } 70 \text { years of age with } \\
\text { established OP and prior } \\
\text { vertebral fracture }\end{array}$ & Vs no treatment & Risedronate was dominant \\
\hline $\begin{array}{l}\text { Ding et al. }{ }^{58}(2008) \\
\text { Japan }\end{array}$ & Women $\geq 55$ years & Vs no treatment & $\begin{array}{l}\text { Assuming a maximum cost per QALY of } 100,000 \$ \text { and after } \\
\text { measuring BMD at }>70 \text { years with vertebral FX in the } 2 \text { previous } \\
\text { years, treating those osteoporotic was cost-effective. } \\
\text { Measure BMD in those without prior vertebral Fx was not } \\
\text { cost-effective even in women } \geq 85 \text { years. }\end{array}$ \\
\hline $\begin{array}{l}\text { Grima et al. }{ }^{59}(2008) \\
\text { Canada }\end{array}$ & Women $\geq 65$ years of age & $\begin{array}{l}\text { Branded risedronate versus } \\
\text { generic or branded alendronate }\end{array}$ & $\begin{array}{l}\text { Risedronate was cost-effective compared to generic or branded } \\
\text { alendronate. } \\
7 \text { fewer fractures in } 1000 \text { patients and additional benefit of } 3.43 \\
\text { QALY due to lower mortality and morbidity in the risedronate } \\
\text { group. } \\
\text { Avoided cost increase due to fracture of } 1867 \$ \text { and QALY gained of } \\
3877 \$ \text { for risedronate compared with generic alendronate. }\end{array}$ \\
\hline $\begin{array}{l}\text { Thompson et al. }{ }^{60}(2010) \\
\text { Germany }\end{array}$ & Women $\geq 65$ and T-score $\leq-2.5$ & $\begin{array}{l}\text { Branded risedronate with } \\
\text { generic alendronate }\end{array}$ & Risedronate reduced costs \\
\hline $\begin{array}{l}\text { Berto et al. }{ }^{61}(2010) \\
\text { Italy }\end{array}$ & $\begin{array}{l}\text { Women }>65 \text { with prior } \\
\text { vertebral fracture }\end{array}$ & Vs generic alendronate & $\begin{array}{l}\text { ICER range from } 36,099 €(65-69 \text { years) to cost savings from } 75 \text { to } \\
79 .\end{array}$ \\
\hline $\begin{array}{l}\text { Borgstrom et al. }{ }^{62} \text { (2010) } \\
\text { Sweden }\end{array}$ & Women $>50$ using FRAX & Vs no treatment & $\begin{array}{l}\text { Treatment cost-effective in elderly women } 65 \text { years of age, with } \\
\text { OP, assuming a willingness to pay of } 30,000 £ \text { per QALY. Effective in } \\
\text { all ages if previous fracture or family history of hip fractures with } \\
\text { limit BMD }\end{array}$ \\
\hline
\end{tabular}


Table 3

Cost-effectiveness of zoledronic acid.

\begin{tabular}{|c|c|c|c|}
\hline Author/country & Study population & Drug & Results \\
\hline $\begin{array}{l}\text { Akehurst et al. }{ }^{63} \text { (2011) } \\
\text { Finland, Norway, and the } \\
\text { Netherlands }\end{array}$ & $\begin{array}{l}\text { Women } 50-80 \text { years of age, } \\
\text { previous fracture and T-score } \\
-2.5\end{array}$ & $\begin{array}{l}\text { Vs calcium/vit D, } \\
\text { biphosphonates }\end{array}$ & $\begin{array}{l}\text { Reduced costs with regard to } \mathrm{Ca} / \mathrm{vitD} \text { and branded alendronate. } \\
\text { Compared with generic alendronate) }\end{array}$ \\
\hline $\begin{array}{l}\text { Fardellone et } \text { al. }^{64}(2010) \\
\text { France }\end{array}$ & Women $>65$ years of age & Vs other treatments & The cost per vertebral fracture avoided was $1497 €$ versus $1685 €$ \\
\hline $\begin{array}{l}\text { Moriwaki et al. }{ }^{65}(2017) \\
\text { Japan }\end{array}$ & $\begin{array}{l}\text { Women } 70 \text { years of age, with } \\
\text { OP and prior vertebral Fracture }\end{array}$ & Vs weekly alendronate & $\begin{array}{l}\text { Zoledronic acid less effective and more costly for those with a risk } \\
\text { factor (tobacco, alcohol, prior family history of fractures). Alendronate } \\
\text { dominates but with very small increase in QALY. Considering the } \\
\text { advantage of the yearly dosage (better adherence), zoledronic acid } \\
\text { could be a cost-effective option. }\end{array}$ \\
\hline
\end{tabular}

Table 4

Cost-effectiveness of denosumab.

\begin{tabular}{|c|c|c|c|}
\hline Author/country & Population & Drug & Results \\
\hline $\begin{array}{l}\text { Parthan } \mathrm{A}^{55} \\
\text { Sweden }\end{array}$ & $\begin{array}{l}\text { Males with osteoporosis }>74 \text { years of } \\
\text { age }\end{array}$ & $\begin{array}{l}\text { Denosumab versus: } \\
\text { Biphosphonates } \\
\text { Strontium ranelate } \\
\text { Ibandronate }\end{array}$ & $\begin{array}{l}\text { Denosumab was cost effective with regard to the others up to } 66,000 € \\
\text { per QALY gained. } \\
\text { This is attributed to the greater reduction in fracture risk and the } \\
\text { longer persistence with Denosumab. }\end{array}$ \\
\hline $\begin{array}{l}\text { Mori T } \\
\text { Japan }\end{array}$ & Women with osteoporosis $>65$ & $\begin{array}{l}5 \text { years: } \\
\text { Denosumab } \\
\text { Weekly alendronate } \\
\text { No treatment }\end{array}$ & $\begin{array}{l}\text { Denosumab was found to achieve greater cost savings at the age of } 75 \\
\text { and } 80 \text {. The ICER decreased from } 30,100 \$ / Q A L Y \text { at age } 65 \text { to } \\
6700 \$ / Q A L Y \text { at age } 70 \text {. }\end{array}$ \\
\hline $\begin{array}{l}\text { Silverman } S^{77} \\
\text { USA }\end{array}$ & Males average age $78 \mathrm{~T}$-score -2.12 & $\begin{array}{l}\text { Denosumab } \\
\text { Biphosphonates } \\
\text { Teriparatide }\end{array}$ & $\begin{array}{l}\text { Alendronate was the least expensive but } \\
\text { Denosumab had a lower cost and better QALY per patient. } \\
\text { It resulted in } 16,900 \$ \text { per QALY gained }\end{array}$ \\
\hline $\begin{array}{l}\text { Darbá J } \\
\text { Spain }\end{array}$ & Osteoporosis T score -2.5 & $\begin{array}{l}\text { Denosumab } \\
\text { Biphosphonates } \\
\text { Strontium R } \\
\text { No treatment }\end{array}$ & $\begin{array}{l}\text { The increase in ICER cost-effectiveness was: } \\
\text { Denosumab } 6823 € \\
\text { No treatment } 16,294 € \\
\text { Biphosphonates between } 4800 \text { and } 2200 € \text { per QALY gained } \\
\text { (In patients with } 2 \text { of the following: }>70 \text {, with T-score }-3.5 \text { or previous } \\
\text { fracture is more cost effective than the rest) }\end{array}$ \\
\hline $\begin{array}{l}\text { Stolshek B }{ }^{79} \\
\text { USA }\end{array}$ & $\begin{array}{l}>75 \text { women, T-score }-2.5 \text { and previous } \\
\text { fracture }\end{array}$ & $\begin{array}{l}\text { Denosumab versus } \\
\text { zoledronic acid }\end{array}$ & $\begin{array}{l}\text { Denosumab was cost effective using 100,000\$ per QALY gained vs } \\
\text { zoledronic acid }\end{array}$ \\
\hline
\end{tabular}

Other works analyze the effect of teriparatide in patients older and younger than 80 years of age. ${ }^{84}$ They study the efficacy of the drug based on the analysis of BMD and the bone markers in both groups, and did not find any significant differences. They concluded that their effect is not conditioned by age or by the complexity of the patient. Although it was not a study that was methodologically focused on fractures, there were also no notable differences in this aspect at the two year follow-up (13 fractures in the group over 80 with low BMD and/or a history of a fracture versus 10 in those under 80 years of age with lower fracture risk).

In the well-known EFOS study, ${ }^{85}$ although it is an observational study, it analyses the incidence of clinical fractures, lumbar pain, and quality of life in women over the age of 75 , in treatment with teriparatide for 18 months, and after this, with an extension for another 18 months, with positive results noted in all of the parameters studied. In another trial - this time randomized which compared teriparatide against risedronate, after 26 weeks, an initial improvement in functional parameters was observed in patients (average age 77) treated with the bone growth drug after a pertrochanteric hip fracture. ${ }^{86}$ The extension of the treatment to 78 weeks ${ }^{87}$ showed a significant increase in bone mineral density in both the lumbar level and femoral neck in the patients treated with teriparatide. One of the conclusions of the study was that both drugs are safe when used in the period immediately following the fracture, because no problems of consolidation of the fractures was observed. Recently, another published trial, also randomized, known as the VERO trial, ${ }^{88}$ compares teriparatide and risedronate. Risedronate is an active comparator that reduces vertebral and non-vertebral fractures compared with placebo with a $60 \%$ relative reduction in the risk of hip fractures in elderly patients with osteoporosis and prevalent spine fractures in the HIP trial. ${ }^{93,89}$ Previous to this paper, no head-to-head studies have compared the effects of antiresorptives and bone-forming medications on reducing the risk of fractures as the primary outcome. Although only close to $20 \%$ of the patients included were older than 80 years, the results in the reduction of a new vertebral fractures were notable for the patients who received teriparatide, with an absolute risk reduction after two years of $6.6 \%$. These data inform of the superior anti-fracture efficacy of this anabolic drug in the management of severe osteoporosis

\section{Reviews of the efficacy and effectiveness of the most widely-used osteo-protective drugs}

Some reviews show, with high-grade evidence, that biphosphonates (alendronate, ibandronate, risedronate, zoledronic acid) denosumab and teriparatide reduce fractures in comparison with a placebo in post-menopausal women with fracture risk of 0.4-0.6 for vertebral fractures and 0.6 to 0.8 for non-vertebral fractures. The CPG of the American College of Physicians recommends giving these drugs to women with osteoporosis. ${ }^{15,17}$ There are no comparative studies between drugs, and several meta-analyses found no superiority of one drug over the other. ${ }^{15}$

In terms of secondary prevention, in the Saito review ${ }^{16}$ with 26 studies selected, they found that all of the drugs evaluated (biphosphonates and teriparatide) were able to prevent fractures (reduction of the relative risk of new fractures between 0.38 and 0.77), although teriparatide with lower NNT for vertebral fractures and biphosphonates for non-vertebral fractures. This meta-analysis did not include denosumab, because it had only a single trial, but they did mention the Palacios trial ${ }^{73}$ in which denosumab reduced secondary vertebral and non-vertebral fractures.

Table 5 shows the relative risk of the most widely-used treatments for each type of fracture and the reduction in absolute risk 
Table 5

Relative risk, reduction of absolute risk of fractures under anti-osteoporotic treatment for secondary prevention of fractures. ${ }^{55,90}$

\begin{tabular}{|c|c|c|c|c|}
\hline RR/ARR NNT & Hip & Vertebral & Other & Publication \\
\hline Denosumab & $0.38 / 0.3$ NNT 200 & $0.36 / 4.5$ NNT 22 & $0.84 / 1.5 N N T 67$ & $\begin{array}{l}\text { Boonen } 2011^{71} \\
\text { McClung } 2011^{72} \\
\text { Marco Tejón R } 2017^{90}\end{array}$ \\
\hline \multicolumn{5}{|l|}{ Biphosphonates } \\
\hline Alendronate & $0.62 / 1.1$ NNT 90 & 0.62/6.8NNT 15 & $0.82 / 2.1$ NNT 36 & $\begin{array}{l}\text { NICE } 2008^{91} \\
\text { Inderjeeth } 2009^{92} \\
\text { Marco Tejón R } 2017^{90}\end{array}$ \\
\hline Zolendronate & 0.82/0.9 NNT 91 & $0.34 / 7$ NNT 14 & $0.73 / 2.5$ NNT 40 & $\begin{array}{l}\text { Boonen } 2010^{93} \\
\text { Marco Tejón R } 2017^{90}\end{array}$ \\
\hline Risedronate & $0.85 /$ NS NNT NS & $0.56 / 5$ NNT 20 & $0.80 / 2.3$ NNT 43 & $\begin{array}{l}\text { McClung } 2001^{89} \\
\text { Inderjeeth } 2009^{92} \\
\text { NICE 2008 } \\
\text { Marco Tejón R } 2017^{90}\end{array}$ \\
\hline Ibandronate & $1.00 /$ NS NNT NS & $0.51 / 4.9$ NNT 20 & $1.00 /$ NSNNT NS & $\begin{array}{l}\text { NICE } 2008^{91} \\
\text { Marco Tejón R } 2017^{90}\end{array}$ \\
\hline Teriparatide & $0.25 /$ NS NNT NS & $0.35 / 7.7$ NNT 11 & $0.47 / 3$ NNT 34 & $\begin{array}{l}\text { NICE } 2008^{91} \\
\text { Marco Tejón R } 2017^{90}\end{array}$ \\
\hline
\end{tabular}

RR, relative risk; ARR, absolute reduction of risk versus a placebo; NNT, number needed to treat for secondary prevention.

Table 6

Factors that influence the cost-effectiveness of the different drugs. ${ }^{94}$

\begin{tabular}{|c|c|c|}
\hline \multicolumn{2}{|c|}{ Drug and comparator } & \multirow[b]{2}{*}{$\begin{array}{l}\text { Limit } \\
\text { Accepted limit of } \\
\text { cost-effectiveness } \\
45,000 € \text { per QALY } \\
\text { gained in women } \\
60-65 \text { years of age } \\
\text { with low bone mass }\end{array}$} \\
\hline No treatment & $\begin{array}{l}\text { Alendronate, risedronate, and } \\
\text { zoledronate cost effective }\end{array}$ & \\
\hline Denosumab & $\begin{array}{l}\text { More cost-effective (especially } \\
\text { in high-risk sub-groups) than } \\
\text { risedronate, branded } \\
\text { alendronate, and zoledronate. } \\
\text { Cost-effectiveness less } \\
\text { favourable when the } \\
\text { comparator is generic } \\
\text { alendronate. }\end{array}$ & $\begin{array}{l}\text { Reduces costs at } 75- \\
80 \text { years of age in any } \\
\text { of the three } \\
\text { perspectives (social, } \\
\text { healthcare, } \\
\text { and government) }\end{array}$ \\
\hline & $\begin{array}{l}\text { More cost-effective in } \\
\text { comparison with weekly } \\
\text { alendronate }^{76}\end{array}$ & \\
\hline Risedronate & $\begin{array}{l}\text { Better than generic } \\
\text { alendronate }\end{array}$ & \\
\hline Zoledronic acid & $\begin{array}{l}\text { More cost-effective than } \\
\text { branded biphosphonate }\end{array}$ & \\
\hline Teriparatide & $\begin{array}{l}\text { Cost-effective compared with } \\
\text { oral biphosphonates in severe } \\
\text { post-menopausal OP }\end{array}$ & \\
\hline Age & $\begin{array}{l}\text { The older the patient, the more } \\
\text { cost-effective the treatment }\end{array}$ & \\
\hline Fracture risk & $\begin{array}{l}\text { The higher the fracture risk, } \\
\text { the more cost-effective the } \\
\text { treatment }\end{array}$ & \\
\hline Adherence & $\begin{array}{l}\text { The better the adherence, the } \\
\text { better the cost-effectiveness }\end{array}$ & \\
\hline Countries & $\begin{array}{l}\text { What may be cost-effective } \\
\text { in one country may not be } \\
\text { cost-effective in another }\end{array}$ & \\
\hline
\end{tabular}

in comparison with a placebo, as well the NNT to prevent fragility fractures, according to several studies.

In terms of cost-effectiveness, this is determined by numerous factors and some of them are different in each country, such as the incidence of fracture and treatment cost (Table 6). Other factors, such as adherence, the drug used to compare, BMD, age, and life expectancy also influence effectiveness. When it is assumed that all patients have the same risk and the intervention thresholds are based on a limited number of clinical characteristics such as age and BMD, there is a risk of not applying an adequate treatment.
Table 7

Current annual cost of anti-osteoporotic drugs in Spain.

\begin{tabular}{|c|c|}
\hline & Annual price of osteo-protective drugs \\
\hline Alendronate Cost/year & $9.99 € \times 12$ months $119.88 € /$ year \\
\hline Risedronate Cost/year & $19.84 € \times 12$ months $238.56 € /$ year \\
\hline Zolendronate Cost/year & $23.42 € /$ year \\
\hline Denosumab Cost/year & $225.59 € \times 2$ times/year $451.18 € /$ year \\
\hline Teriparatide $^{\mathrm{a}}$ Cost/year & $405.38 € \times 12$ months $4864.56 € /$ year \\
\hline
\end{tabular}

a Teriparatide will become generic soon

In the economic evaluation of the drug, it is better to base intervention thresholds on the long-term probability of fracture and use data for diverse populations (with different risks), taking into account the regional factors (cost and epidemiology of fractures in the country). ${ }^{94}$ Table 7 shows the current annual cost in Spain of the drugs covered in this analysis.

It should be noted that in a recent study done in the US on thousands of individuals with previous fractures (vertebral, radius, or hip), the risk of dying especially in subjects over the age of 85 with several comorbidities, was higher than the risk of suffering another fracture. In this study, it was estimated that the NNT for 5 years to prevent a second osteoporotic fracture would range between 8 and 65 and is similar to the NNT of other preventive strategies (aspirin, statins, and b blockers). ${ }^{95}$

For this reason, when deciding whether to prescribe antiosteoporotics for the elderly, the patient's estimated survival (after the fracture that occurred or the risk of suffering a fracture) must be considered along with the effect of the treatments in terms of the prevention of new fractures and a possible reduction of mortality.

\section{Effect of osteoprotective treatments on mortality}

The relationship between treatment of osteoporosis and mortality is a controversial topic, with several authors indicating the existence of a reduction in the risk of dying in patients who are administered osteoprotective treatments. ${ }^{96-102}$ In 2010, a metaanalysis $^{102}$ was published with the objective of determining the degree to which the drugs that are effective in treating osteoporosis, in addition to reducing the incidence of new fractures, manage to reduce mortality in patients over the age of 50 with an established fracture (vertebral and non-vertebral). It includes 8 double-blind, placebo-controlled randomized clinical trials, with a 3 -year follow-up, and it found a significant reduction of $11 \%$ in mortality, regardless of age and the incidence of fracture. It detected 
that the reduction in mortality is mainly observed in the studies done on the oldest, most fragile population, with a higher fracture risk and higher mortality rate. This study did not find differences in mortality depending on the type of drug analyzed (biphosphonates, strontium ranelate, or denosumab), although some authors indicate that the use of calcitonin could have less of an influence on mortality than other osteoprotectors. ${ }^{103}$

Most of the studies that analyze the relationship between osteoprotective treatment and mortality have been done on biphosphonates.

In 2011, Lyles $^{98}$ carried out a double-blind placebo-controlled randomized trial, with an average follow-up of almost two years, which indicated a $28 \%$ reduction in death due to any cause after the administration of intravenous zoledronic acid in the first three months following a hip fracture. Cengiz ${ }^{104}$ found a reduction in mortality after one year of $20.2 \%$ in pertrochanteric fractures. It is not clear when the optimum moment for the administration of zoledronic acid is, but it appears that the beneficial effect on mortality is lower if it is administered in the first two weeks after the fracture. ${ }^{105}$

In 2012, Grey ${ }^{4}$ published a systematic review that indicated a reduction in the risk of dying after the use of biphosphonates between 24 and $66 \%$. Other authors ${ }^{99}$ have found that treatment with these drugs is an independent factor for the reduction of mortality due to any cause, such that for each year of treatment with biphosphonates, the relative risk of dying is reduced by $63 \%$ in patients with hip fractures over the age of 50 .

Center ${ }^{106}$ designed a study over the course of 18 years with the goal of analysing the association between biphosphonates and the risk of dying, independently from the type of fracture. It found a reduction in mortality in the group of women with and without fractures of $69 \%$, with a reduction of $76 \%$ in the sub-group of women without fractures.

If we take into account that the treatment for osteoporosis, in addition to reducing the risk of FV and FNV mentioned earlier, reduces mortality by between $11 \%$ and $70 \%$, this is one more reason to initiate the treatment in elderly patients with fractures.

There are several theories regarding how osteoprotective treatment could reduce mortality, although the specific mechanism is not precisely known. On one hand, there is the reduction of the risk of new fractures and the morbimortality associated with them if they do occur ${ }^{100}$ but it appears that the percentage of mortality justified for this reason is low, because most of the patients who die did not develop new fractures before dying. ${ }^{95,102,107}$ It has also been indicated that biphosphonates could have a protective effect on the mortality associated with the appearance of pneumonia and cardiovascular events such as acute myocardial infarction or arrhythmia, ${ }^{107-109}$ although it is not clear that they achieve a reduction in the incidence of these complications. ${ }^{98,106,110}$ It has been suggested that biphosphonates could have a protective effect in the atherogenic process. ${ }^{111}$ It is possible that the treatment for osteoporosis involves an improvement in the physiological reserve and in the situation of frailty of the patient, improving their capacity to respond to other diseases that may arise. ${ }^{107}$ This theory would be in line with the fact that a larger reduction in mortality has been observed in groups that were previously more frail. ${ }^{102}$

\section{Factors to be taken into account to indicate the treatment of osteoporosis in the elderly}

\section{Fracture risk}

2. Time that it takes the treatment to be effective

3. Prediction of mortality

4. Method for the treatment of fractures and the secondary prevention of osteoporosis: FLS and Orthogeriatric Units.

\section{Fracture risk}

Several factors related to osteoporotic fracture risk have been described and they are those that are evaluated in the screening scales such as the FRAX or Q-Fracture (age, gender, smoking and alcohol habits, diabetes, parents with osteoporosis or hip fractures, institutionalized, history of fragility fractures or falls, dementia, cancer, COPD/asthma, cardiopathy or CVA, liver or kidney disease, Parkinson's, rheumatoid arthritis, digestive malabsorption disease, endocrine issues, epilepsy, or anti-epileptic drugs, antidepressants, corticosteroids, or estrogens). ${ }^{112}$ In addition, therapeutic recommendations have been made based on the 10 -year risk of suffering osteoporotic or hip fractures. But there are already several studies that relate some specific factors with imminent fracture risk, such as: advanced age, diseases with physical affectation or functional deterioration, specific comorbidities (psychosis, Alzheimer's and diseases of the CNS), previous falls or factors that contribute to them (customary treatment with psychotropics) and alterations of bone mineral metabolism and/or history of osteoporotic fractures. ${ }^{113}$ On the other hand, imminent risk of suffering a second major osteoporotic fracture increases with age, is more frequent in women, and is more likely immediately after the first fracture. ${ }^{114}$

Therefore, it is in this profile of a frail, aged woman, with a recent fracture in which the benefit of the prevention of fragility fractures must be evaluated. And the decision must be quick, due to the imminent risk and because the fracture is going to generate a dependency that is difficult to reverse, ultimately worsening her precarious functional situation.

\section{Time that it takes the treatment to be effective}

There is not much available bibliography that provides information on the treatment time needed to reduce the incidence of fractures. It has already been mentioned that in geriatric patients, there are many more variables that contribute to fractures, especially those related to falls, which generates much confusion when determining the effect of anti-osteoporotic treatment. In general, the authors take about a period that ranges from between 6 months to prevent vertebral fractures and 18-24 months to reduce the risk of new hip fractures, and of a half year. ${ }^{14,37,70,115,116}$ Adherence directly influences the efficacy of the drug and in this concept, denosumab and teriparatide are the drugs that achieve the greatest adherence. $^{117}$

This detail, along with the time necessary for the drug to show its effectiveness, becomes especially important in the elderly population, for which we have to estimate survival longer than the value mentioned (6-12 months) before initiating treatment, if what we want to do is prevent new fractures.

\section{Prediction of mortality}

Despite the substantial risk of death after an osteoporotic fracture, the risk of a new fracture generally is high enough to justify a preventive treatment for osteoporosis, ${ }^{95}$ unless there is a very high expectation of mortality in the short term. It is therefore important to know and predict the increased mortality involved with these fractures, especially hip fractures, which is associated with the greatest risk.

In the study by Alonso, ${ }^{118}$ factors such as age, male gender, comorbidity, admittance in summer, low score on the Barthel Index upon admittance and discharge, or elevated levels of urea, creatinine, and sodium upon arrival at the emergency room significantly increase the risk of dying in the first year after the fracture. In addition to these baseline factors, it also found that patients who develop respiratory complications, delirium, malnutrition, or hydroelectrolytic alterations during admittance, as 
well as those who require re-hospitalization for any reason during the first month, have an increased risk of dying during the first year. $\mathrm{Hu}^{119}$ and $\mathrm{Smith}^{120}$ found similar preoperative factors in two meta-analyses that give a prediction of mortality with strong evidence.

In order to be able to calculate the individual mortality risk that a specific patient has after suffering a hip fracture, more than 25 predictive tests have been described. ${ }^{121,122}$ Of all the available scales, the Nottingham Hip Fracture Score (NHFS) ${ }^{123}$ appears to be the most suitable for determining the risk of dying in patients who suffer hip fractures. ${ }^{121}$ It has been validated in the British population in which it was designed to predict mortality within one month ${ }^{122-126}$ and one year ${ }^{127}$ of the fracture.

Knowing the factors associated with higher mortality after fragility fractures or the application of instruments such as the NHFS can help make clinical decisions for these patients, since they make it possible to adapt the therapeutic strategies based on the life prognosis of each individual.

But the most important reason to predict something as serious as mortality is the possibility of trying to avoid it. With regard to the factors associated with mortality after hip fracture, several have been identified that are modifiable, such as avoiding orthopaedic treatment and intervening as soon as possible, achieving maximum functional recovery by means of rehabilitation, early detection and treatment of perioperative complications, or, as indicated previously, the treatment of osteoporosis. ${ }^{118}$ It is in this group of interventions where the Orthogeriatric Units have demonstrated their benefits.

\section{Method for the treatment of fractures and the secondary prevention of osteoporosis: FLS and Orthogeriatric Units}

Currently, the principal CPGs recommend orthogeriatric collaboration in the treatment of patients with hip fractures, ${ }^{128}$ because it has demonstrated important benefits such as reduction in hospital complications, higher rate of surgical treatment, earlier surgery, shorter average hospital stay, improvement in the functional situation upon discharge and long term, greater prescription of treatment for osteoporosis upon discharge, better planning of the level of care after hospital discharge, lower rate of re-admittance and overall, a reduction in mortality. ${ }^{129-143}$ There are numerous studies that indicate that the multidisciplinary treatment of hip fractures improves the percentage of patients who receive treatment for osteoporosis. ${ }^{131-135}$ Fisher finds an increase in the prescription of $12 \%$ to $69 \%$ when switching from a system in which the geriatrics department only participated sporadically by means of interconsultation to a system of orthogeriatric collaboration with daily monitoring of patients. ${ }^{132}$ Sánchez ${ }^{134}$ obtained similar percentages after the application of a clinical method for the multidisciplinary treatment of hip fractures in their centre, with an increase in prescription from $14.8 \%$ to $76 \%$.

Recently, fracture units (FLS) have also been implemented, where the cause is studied, patients are monitored, and secondary prevention of osteoporosis is undertaken, also achieving better adherence to the treatment, improvement in BMD, and a reduction in new fractures as well as mortality. $137,144,145$

Both methods, Orthogeriatric Units and FLS, must be considered as a work mode when the objective is the secondary prevention of fractures in geriatric patients.

To provide a practical summary, the authors propose that in patients with high fracture risk (evaluated according to FRAX, Q fracture, densitometry, or with factors related to imminent fracture risk), that life expectancy be estimated using a method such as the NHFS, and if life expectancy is greater than one year and the patient maintains the ability to walk, the initiation of treatment for

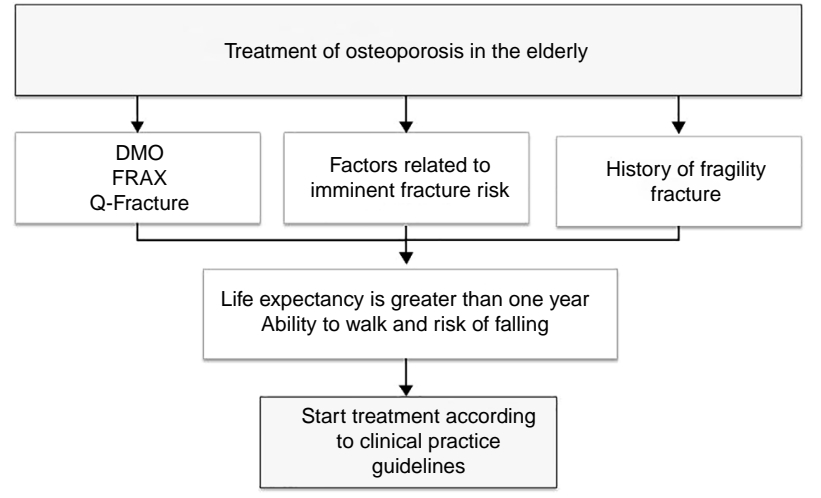

Fig. 1. Aspects that influence the decision of treatment of osteoporosis in the elderly (contribution of the authors).

osteoporosis is recommended with the intention of reducing the risk of new fragility fractures (Fig. 1).

\section{Discussion}

In this paper we have intended to do a review of different factors that need to be taken into account when managing specially elderly patients in risk of suffering a fracture. It is true that the vast majority of clinical essays and studies with higher clinical relevance are done with younger patients while the average age of most of the fractured patients is more elevated. This would be probably due to recruitment problems and follow up issues, being more expensive and difficult in patients in their eighties. But it is precisely in this age group where it is more interesting to contemplate some kind of treatment, as the risk of fracture is higher here. NNTs, costs and therefore efficiency are probably optimum in this type of patients, but we understand that even though it is information of high clinical value, it is more complicated to get it.

It is true that our work is not a "systematic review" that follows the data gathering protocols on a standardized way and it is not a meta-analysis either with which we could obtain conclusions with any degree of certainty. This could involve some degree of subjectivity in the analysis, but our main objective is above all to draw the attention to the elderly population which has more fracture risk and which is not generally well managed from the prevention's point of view. Chronological age is not a valid guideline anymore for making certain decisions, as life expectancy and its quality are more important, as it has been developed through this manuscript. It is true that in some patients clinically very deteriorated, the decision to take must be focused specially on the comfortableness of the future of these patients, but there are many others in which some strategies may reduce the probability of those aggressive fractures happening.

We have not wanted to deal with falls in our study. We are aware that a fracture is generally a consequence of a fall and that the approach for reducing fractures must be developed concurrently with a pharmacological intervention. We have not detailed it intentionally as we consider it a large enough subject as to appear on a publication specifically dedicated to it.

From the studied meta-analysis that have been studied, $32,34,146-148$ we can declare that we have effective treatments for fracture reduction, that alendronate and zolendronate, in their generic version, are probably the most cost-effective and that the effect of the drug does not depend on the age of the patients. Zolendronate has the inconvenience of being exclusively for intra-hospital treatment. We have effective "weapons". The factors to take into consideration when indicating a treatment are many, but each patient is different and requires a personalized 
evaluation. We have expressed the ones we consider most relevant taking into account characteristics of the patient and the drug. An undeniable issue is that a drug, in order to be effective, it must be taken by the patient. Medication adherence in this type of processes, in which patients do not perceive their real importance, can usually be improved, with a clear decrease in treatments in a year time. Parenteral drugs have better adherence than oral ones, which depending on the type of patient, may have significance. ${ }^{117}$

Finally, we emphasize the need of a global treatment, not just for the fracture but also for the patient that has the fracture. Orthogeriatric models of care have demonstrated being the future for the elderly fractured patient, with a special interest in the organization of an additional estructure of secondary prevention that it is giving extraordinary results, the Fracture Liason Services. ${ }^{128,142-145}$

\section{Conclusions}

Studies have shown that the efficacy of the treatment of osteoporosis in the elderly population is similar to that of the adult population.

In terms of the effectiveness of these treatments in the elderly, especially after suffering a major fracture, they are more costeffective than in adults. This is because of the higher risk of suffering new fractures and the serious functional, social and economic repercussions of those new fractures.

The cost-effectiveness of each drug varies in each country because it is influenced by factors such as the incidence of fractures and the price of drugs, which are different in each country. It also varies according to other factors related to the patient, such as adherence, the comparator that is used, and the rest of the clinical characteristics of the patient.

Before deciding on the therapeutic intervention of osteoporosis in the elderly, numerous factors must be taken into account, such as the individual fracture risk of the patient, their life expectancy, the risk of side effects or interactions and comorbidities, to make a suitable selection of the drug.

Orthogeriatric Units have demonstrated clinical benefits and improvements in the care of elderly patients with hip fractures, in both the acute and ambulatory follow-up. The implementation of FLS in coordination with the Orthogeriatric Units can improve the secondary prevention approach and the overall care of orthogeriatric patients.

\section{Conflict of interests}

PSL has been a speaker at a scientific event of Amgen. IEF has received speaker honoraria from Lilly. MPML has received speaker honoraria from Amgen and Lilly. The rest of the authors declares no conflict of interests.

\section{References}

1. Azagra R, López-Expósito F, Martín-Sánchez JC, Aguyé A, Moreno N, Cooper C, et al. Changing trends in the epidemiology of hip fracture in Spain. Osteoporos Int. 2014;25:1267-74, http://dx.doi.org/10.1007/s00198-013-2586-0.

2. Siris ES, Genant HK, Laster AJ, ChenD.F P., Misurski JA, Krege H. Enhanced prediction of fracture risk combining vertebral fracture status and BMD. Osteoporos Int. 2007;18:761-70, http://dx.doi.org/10.1007/s00198-006-0306-8.

3. Bliuc D, Nguyen ND, Milch VE, Nguyen TV, Eisman JA, Center JR. Mortality risk associated with low-trauma osteoporotic fracture and subsequent fracture in men and women. JAMA. 2009;301:513-21, http://dx.doi.org/ 10.1001/jama.2009.50.

4. Grey A, Bolland MJ. The effect of treatments for osteoporosis on mortality. Osteoporos Int. 2013;24:1-6, http://dx.doi.org/10.1007/s00198-012-2176-6.

5. Kanis JA, Oden A, Johnell O, De Laet C, Jonsson B, Oglesby AK. The components of excess mortality after hip fracture. Bone. 2003;32:468-73, http://dx.doi.org/10.1016/S8756-3282(03)00061-9.
6. Browner WS, Pressman AR, Nevitt MC, Cummings SR. Mortality following fractures in older women. The Study of Osteoporotic fractures. Arch Intern Med. 1996;156:1521-5, http://dx.doi.org/10.1001/archinte.1996.00440130053006.

7. Roche JJ, Wenn RT, Sahota O, Moran CG. Effect of comorbidities and postoperative complications on mortality after hip fracture in elderly people: prospective observational cohort study. BMJ. 2005;331:1374, http://dx.doi.org/10.1136/bmj.38643.663843.55.

8. Kannegaard PN, van der Mark S, Eiken P, Abrahamsen B. Excess mortality in men compared with women following a hip fracture. National analysis of comedications, comorbidity and survival. Age Ageing. 2010;39:203-9, http://dx.doi.org/10.1093/ageing/afp221.

9. Berry SD, Samelson EJ, Hannan MT, McLean RR, Lu M, Cupples LA, et al. Secondhip fracture in older men and women: Second Framingham Study. Arch Intern Med. 2007;167:1971-6, http://dx.doi.org/10.1001/archinte.167.18.1971.

10. Cauley JA, Lui LY, Barnes D, Ensrud KE, Zmuda JM, Hillier TA, et al. Successful skeletal aging: a marker of low fracture risk and longevity. The Study of Osteoporotic Fractures (SOF). J Bone Miner Res. 2009;24:134-43, http://dx.doi.org/10.1359/jbmr.080813.

11. Jönsson B. CODE-2 Advisory Board. Revealing the cost of Type II diabetes in Europe. Diabetologia. 2002;45:S5-12, http://dx.doi.org/ 10.1007/s00125-002-0858-x.

12. Burge R, Dawson-Hughes B, Solomon DH, Wong JB, King A, Tosteson A. Incidence and economic burden of osteoporosis-related fractures in the United States, 2005-2025. J Bone Miner Res. 2007;22:465-75, http://dx.doi.org/10.1359/jbmr.061113.

13. González Montalvo JI, Gotor Perez P, Martín Vega A, Alarcón Alarcón T, Mauleón Alvarez de Linera JL, Gil Garay E, et al. La unidad de ortogeriatría en agudos. Evaluación de su efecto en el curso clínico de los pacientes con fractura de cadera y estimación de su impacto económico. Rev Esp Geriatr Gerontol. 2011;46:193-9, http://dx.doi.org/10.1016/j.regg.2011.02.004.

14. Rizzoli R, Branco J, Brandi ML, Boonen S, Bruyére O, Cacoub P, et al. Management of osteoporosis of the oldest old. Osteoporos Int. 2014;25:2507-29, http://dx.doi.org/10.1007/s00198-014-2755-9.

15. Crandall CJ, Newberry SJ, Diamant A, Lim YW, Gellad WF, Booth MJ, et al. Comparative effectiveness of pharmacologic treatments to prevent fractures: an updated systematic review. Ann Intern Med. 2014;161:711-23, http://dx.doi.org/10.7326/M14-0317.

16. Saito T, Sterbenz JM, Malay S, Zhong L, MacEachern MP, Chung KC. Effectiveness of anti-osteoporotic drugs to prevent secondary fragility fractures: systematic review and meta-analysis. Osteoporos Int. 2017;28:3289-300, http://dx.doi.org/10.1007/s00198-017-4175-0.

17. Qaseem A, Forciea MA, McLean RM, Denberg TD. Clinical Guidelines Committee of the American College of Physicians. Treatment of low bone density or osteoporosis to prevent fractures in men and women: a clinical practice guideline update from the American College of Physicians. Ann Intern Med. 2017;166:818-39, http://dx.doi.org/10.7326/M15-1361.

18. Hawley S, Leal J, Delmestri A, Prieto-Alhambra D, Arden NK, Cooper C, et al. Anti-osteoporosis medication prescriptions and incidence of subsequent fracture among primary hip fracture patients in England and Wales: an interrupted time-series analysis. J Bone Miner Res. 2016;31:2008-15, http://dx.doi.org/10.1002/jbmr.2882.

19. Zeldow D, Lewiecki E, Adler R. Hip fractures and declining DXA testing: at a breaking point? Innov Aging. 2017;1:843, http://dx.doi.org/ 10.1093/geroni/igx004.3036.

20. Boonen S, Lips P, Bouillon R, Bischoff-Ferrari HA, Vanderschueren D, Haentjens P. Need for additional calcium to reduce the risk of hip fracture with vitamin D supplementation: evidence from a comparative metaanalysis of randomized controlled trials. J Clin Endocrinol Metab. 2007;92:1415-23, http://dx.doi.org/10.1210/jc.2006/1404.

21. Bischoff-Ferrari HA, Dawson-Hughes B, Baron JA, Burckhardt P, Li R, Spiegelman $D$, et al. Calcium intake and hip fracture risk in men and women: a meta-analysis of prospective cohort studies and randomized controlled trials. Am J Clin Nutr. 2007;86:1780-90, http://dx.doi.org/10.1093/ajcn/86.5.1780.

22. Tang BM, Eslick GD, Nowson C, Smith C, Bensoussan A. Use of calcium or calcium in combination with vitamin D supplementation to prevent fractures and bone loss in people aged 50 years and older: a meta-analysis. Lancet. 2007;370:657-66, http://dx.doi.org/10.1016/S0140-6736(07)61342-7.

23. Bischof Ferrary HA, Willet WC, Orav EJ, Lips P, Meunier PJ, Lyons RA, et al. A pooled analysis of vitamin D dose requirements for fracture prevention. $\mathrm{N}$ Engl J Med. 2012;367:40-9, http://dx.doi.org/10.1056/NEJMoa1109617.

24. Looker AC. Serum 25-hydroxyvitamin D and risk of major osteoporotic fractures in older U.S. adults. J Bone Miner Res. 2013;28:997-1006, http://dx.doi.org/10.1002/jbmr.1828.

25. Johansson $\mathrm{H}$, Odén A, Kanis J, McCloskey E, Lorentzon M, Ljunggren $\mathrm{O}$, et al. Low serum vitamin D is associated with increased mortality in elderly men: MrOS Sweden. Osteoporos Int. 2012;23:991-9, http://dx.doi.org/ 10.1007/s00198-011-1809-5.

26. Zhao JG, Zeng XT, Wang J, Liu L. Association between calcium or vitamin D supplementation and fracture incidence in community-dwelling older adults: a systematic review and meta-analysis. JAMA. 2017;318:2466-82, http://dx.doi.org/10.1001/jama.2017.19344. 
27. Hiligsmann M, Ben Sedrine W, Bruyère O, Evers SM, Rabenda V, Reginster JY. Cost-effectiveness of vitamin D and calcium supplementation in the treatment of elderly women and men with osteoporosis. Eur J Public Health. 2015;25:20-5, http://dx.doi.org/10.1093/eurpub-cku119.

28. Bolland MJ, Avenell A, Baron JA, Grey A, MacLennan GS, Gamble GD, et al. Effect of calcium supplements on risk of myocardial infarction and cardiovascular events: meta-analysis. BMJ. 2010;341:c3691, http://dx.doi.org/ 10.1136/bmj.c3691.

29. Reid IR. Osteoporosis treatment: focus on safety. Eur J Intern Med. 2013;24:691-7, http://dx.doi.org/10.1016/j.ejim.2013.03.012.

30. Burckhardt P. Potential negative cardiovascular effects of calcium supplements. Osteoporos Int. 2011;22:1645-7, http://dx.doi.org/ 10.1007/s00198-011-1602-5.

31. Kopecky SL, Bauer DC, Gulati M, Nieves JW, Singer AJ, Toth PP, et al. Lack of evidence linking calcium with or without vitamin D supplementation to cardiovascular disease in generally healthy adults: a clinical guideline from the National Osteoporosis Foundation and the American Society for Preventive Cardiology. Ann Inter Med. 2016;165:867-8, http://dx.doi.org/10.7326/M16-1743.

32. Albert SG, Reddy S. Clinical evaluation of cost efficacy of drugs for treatment of osteoporosis: a meta-analysis. Endocr Pract. 2017;23:841-56, http://dx.doi.org/10.4158/EP161678.RA.

33. Khan M, Cheung AM, Khan AA. Drug-related adverse events of osteoporosis therapy. Endocrinol Metab Clin North Am. 2017;46:181-92, http://dx.doi.org/10.1016/j.ecl.2016.09.009.

34. Byun JH, Jang S, Lee S, Park S, Yoon HK, Yoon BH, et al. The efficacy of bisphosphonates for prevention of osteoporotic fracture: an update meta-analysis. J Bone Metab. 2017;24:37-49, http://dx.doi.org/10.11005/jbm.2017.24.1.37.

35. Hochberg MC, Thompson DE, Black DM, Quandt SA, Cauley J, Geusens $\mathrm{P}$, et al. Effect of alendronate on the age-specific incidence of symptomatic osteoporotic fractures. J Bone Miner Res. 2005;20:971-6, http://dx.doi.org/10.1359/JBMR. 050104.

36. NICE 2008. Updated August 2017. Alendronate, etidronate, risedronate, raloxifene, strontium ranelate and teriparatide for the secondary prevention of osteoporotic fragility fractures in postmenopausal women. https://www.nice.org.uk/guidance/ta161/uptake.

37. Boonen S, McClung MR, Eastell R, EI-Hajj Fuleihan G, Barton IP, Delmas $P$. Safety and efficacy of risedronate in reducing osteoporotic women aged 80 and older: implications for the use of antiresorptive agents in the old and oldest old. J Am Geriatr Soc. 2004;52:1832-9, http://dx.doi.org/ 10.1111/j.1532-5415.2004.52506.x.

38. Boonen S, Black DM, Colón-Emeric CS, Eastell R, Magaziner JS, Eriksen EF, et al. Efficacy and safety of a once-yearly intravenous zoledronic acid $5 \mathrm{mg}$ for fracture prevention in elderly postmenopausal women with osteoporosis aged 75 and older. J Am Geriatr Soc. 2010;58:292-9, http://dx.doi.org/ 10.1111/j.1532-5415.2009.02673.x.

39. Nordström P, Toots A, Gustafson Y, Thorngren KG, Hommel A, Nordström A. Bisphosphonate use after hip fracture in older adults: a nationwide retrospective cohort study. J Am Med Dir Assoc. 2017;18:515-21, http://dx.doi.org/10.1016/j.jamda.2016.12.083.

40. Maraldo MV, Vestergaard P, McMurdo MET, Schwarz P. The evidence for antiresorptive osteoporosis treatment in the elderly and old. Eur Geriatr Med. 2010;1:279-92, http://dx.doi.org/10.1016/j.eurger.2010.08.002.

41. Nayak S, Roberts MS, Greenspan SL. Impact of generic alendronate cost on the cost-effectiveness of osteoporosis screening and treatment. PLoS ONE. 2012;7:e32879, http://dx.doi.org/10.1371/journal.pone.0032879.

42. Ni W, Jiang Y. Evaluation on the cost-effective threshold of osteoporosis treatment on elderly women in China using discrete event simulation model. Osteoporos Int. 2017;28:529-38, http://dx.doi.org/10.1007/s00198-016-3751-z.

43. Schousboe JT, Taylor BC, Fink HA, Kane RL, Cummings SR, Orwoll ES, et al. Cost-effectiveness of bone densitometry followed by treatment of osteoporosis in older men. JAMA. 2007;298:629-37, http://dx.doi.org/ $10.1001 /$ jama.298.6.629.

44. van Staa TP, Kanis JA, Geusens P, Boonen A, Leufkens HG, Cooper C. The cost-effectiveness of bisphosphonates in postmenopausal women based on individual long-term fracture risks. Value Health. 2007;10:348-57, http://dx.doi.org/10.1111/j.1524-4733.2007.00188.x.

45. Kanis JA, Borgstrom F, De Laet C, Johansson H, Johnell O, Jonsson $\mathrm{B}$, et al. Assessment of fracture risk. Osteoporos Int. 2005;16:581-9, http://dx.doi.org/10.1007/s00198-004-1780-5.

46. Jansen JP, Gaugris S, Bergman G, Sen SS. Cost-effectiveness of a fixed dose combination of alendronate and cholecalciferol in the treatment and prevention of osteoporosis in the United Kingdom and the Netherlands. Curr Med Res Opin. 2008;24:671-84, http://dx.doi.org/10.1185/030079908X260998.

47. Kanis JA, Adams J, Borgström F, Cooper C, Jönsson B, Preedy D, et al. The cost-effectiveness of alendronate in the management of osteoporosis. Bone. 2008;42:4-15, http://dx.doi.org/10.1016/j.bone.2007.10.019.

48. Kanis JA, McCloskey EV, Johansson H, Strom O, Borgstrom F, Oden A Case finding for the management of osteoporosis with FRAX-assessment and intervention thresholds for the UK. Osteoporos Int. 2008;19:1395-408, http://dx.doi.org/10.1007/s00198-008-0712-1.

49. Hiligsmann M, Ethgen O, Bruyere O, Richy F, Gathon HJ, Reginster JY. Development and validation of a Markov microsimulation model for the economic evaluation of treatments in osteoporosis. Value Health. 2009;12:687-96, http://dx.doi.org/10.1111/j.1524-4733.2008.00497.x.
50. Hiligsmann M, Rabenda V, Gathon HJ, Ethgen O, Reginster JY. Potential clinical and economic impact of nonadherence with osteoporosis medications. Calcif Tissue Int. 2010;86:202-10, http://dx.doi.org/10.1007/s00223-009-9329-4.

51. Hiligsmann M, Reginster JY. Cost-effectiveness of denosumab compared with oral bisphosphonates in the treatment of postmenopausal osteoporotic women in Belgium. Pharmacoeconomics. 2011;29:895-911, http://dx.doi.org/10.2165/11539980-000000000-00000.

52. Pham AN, Datta SK, Weber TJ, Walter LC, Colon-Emeric CS. Cost-effectiveness of oral bisphosphonates for osteoporosis at different ages and levels of life expectancy. J Am Geriatr Soc. 2011;59:1642-9, http://dx.doi.org/ 10.1111/j.1532-5415.2011.03571.x.

53. Lippuner K, Johansson H, Borgstrom F, Kanis JA, Rizzoli R. Cost-effective intervention thresholds against osteoporotic fractures based on FRAX in Switzerland. Osteoporos Int. 2012;23:2579-89, http://dx.doi.org/ 10.1007/s00198-011-1869-6.

54. Moriwaki K, Komaba $H$, Noto S, Yanagisawa S, Takiguchi T, Inoue $H$, et al. Costeffectiveness of alendronate for the treatment of osteopenic postmenopausal women in Japan. J Bone Miner Res. 2013;28:395-403, http://dx.doi.org/10.1002/jbmr.1755.

55. Parthan A, Kruse M, Yurgin N, Huang J, Viswanathan HN, Taylor D. Cost effectiveness of Denosumab versus oral bisphosphonates for postmenopausal osteoporosis in the US. Appl Health Econ Health Policy. 2013;11:485-97, http://dx.doi.org/10.1007/s40258-013-0047-8.

56. Alzahouri K, Bahrami S, Durand-Zaleski I, Guillemin F, Roux C. Costeffectiveness of osteoporosis treatments in postmenopausal women using FRAXTM thresholds for decision. Joint Bone Spine. 2013;80:64-9, http://dx.doi.org/10.1016/j.jbspin.2012.01.001.

57. Wasserfallen JB, Krieg MA, Greiner RA, Lamy O. Cost effectiveness and cost utility of risedronate for osteoporosis treatment and fracture prevention in women: a Swiss perspective. J Med Econ. 2008;11:499-523, http://dx.doi.org/10.3111/13696990802332770.

58. Ding H, Koinuma N, Stevenson M, Ito M, Monma Y. The cost-effectiveness of risedronate treatment in Japanese women with osteoporosis. J Bone Miner Metab. 2008;26:34-41, http://dx.doi.org/10.1007/s00774-007-0794-4.

59. Grima DT, Papaioannou A, Thompson MF, Pasquale MK, Adachi JD. Greater first year effectiveness drives favorable cost-effectiveness of brand risedronate versus generic or brand alendronate: modeled Canadian analysis. Osteoporos Int. 2008;19:687-97, http://dx.doi.org/10.1007/s00198-007-0504-z.

60. Thompson M, Pasquale M, Grima D, Moehrke W, Kruse HP. The impact of fewer hip fractures with risedronate versus alendronate in the first year of treatment: modeled German cost-effectiveness analysis. Value Health. 2010;13:46-54, http://dx.doi.org/10.1111/j.1524-4733.2009.00666.x.

61. Berto P, Maggi S, Noale M, Lopatriello S. Risedronate versus alendronate in older patients with osteoporosis at high risk of fracture: an Italian cost-effectiveness analysis. Aging Clin Exp Res. 2010;22:179-88, http://dx.doi.org/10.1007/bf03324794.

62. Borgstrom F, Strom O, Coelho J, Johansson H, Oden A, McCloskey EV, et al. The cost-effectiveness of risedronate in the UK for the management of osteoporosis using the FRAX ${ }^{\circledast}$. Osteoporos Int. 2010;21:495-505, http://dx.doi.org/10.1007/s00198-009-0989-8.

63. Akehurst $R$, Brereton $N$, Ariely R, Lusa $T$, Groot M, Foss $P$, et al. The cost effectiveness of zoledronic acid $5 \mathrm{mg}$ for the management of postmenopausal osteoporosis in women with prior fractures: evidence from Finland, Norway and the Netherlands. J Med Econ. 2011;14:53-64, http://dx.doi.org/10.3111/13696998.2010.545563.

64. Fardellone P, Cortet B, Legrand E, Bresse X, Bisot-Locard S, Vigneron AM, et al. Cost-effectiveness model of using zoledronic acid once a year versus current treatment strategies in postmenopausal osteoporosis. Joint Bone Spine. 2010;77:53-7, http://dx.doi.org/10.1016/j.jbspin.2009.04.009.

65. Moriwaki K, Mouri M, Hagino H. Cost-effectiveness analysis of once-yearly injection of zoledronic acid for the treatment of osteoporosis in Japan. Osteoporos Int. 2017;28:1939-50, http://dx.doi.org/10.1007/s00198-017-3973-8.

66. Benjamin B, Benjamin MA, Swe M, Sugathan S. Review on the comparison of effectiveness between denosumab and bisphosphonnates in post-menopausal osteoporosis. Osteoporos Sarcopenia. 2016;2:77-81, http://dx.doi.org/10.1016/j.afos.2016.03.003.

67. Törring O. Effects of denosumab on bone density, mass and strength in women with postmenoapusal osteoporosis. Ther Adv Musculoskelet Dis. 2015;7:88-102, http://dx.doi.org/10.1177/1759720x15579189.

68. Popp AW, Zysset PK, Lippuner K. Rebound-associated vertebral fractures after discontinuation of denosumab-from clinic and biomechanics. Osteoporos Int 2016;27:1917-21, http://dx.doi.org/10.1007/s00198-015-3458-6.

69. Papapoulos S, Mcclung MR, Franchimont N, Adachi JD, Bone HG, Benhamou $\mathrm{CL}$, et al. Denosumab (DMAB) treatment for 6 years maintains low fracture incidence in women $\geq 75$ years with postmenopausal osteoporosis (PMO). European Congress on Osteoporosis and Osteoarthritis (ESCEO13IOF): Oral Communication Abstracts. Osteoporos Int. 2013;24 Suppl 1:S45-6, http://dx.doi.org/10.1007/s00198-013-2307-8.

70. Cummings SR, Martin JS, McClung MR, Siris ES, Eastell R, Reid IR, et al. Denosumab for prevention of fractures in postmenopausal women with osteoporosis. N Engl J Med. 2009;361:756-65, http://dx.doi.org/ 10.1056/nejmoa0809493.

71. Boonen S, Adachi JD, Man Z, Cummings SR, Lippuner K, Törring O, et al. Treatment with denosumab reduces the incidence of new vertebral and hip 
fractures in postmenopausal women at high risk. J Clin Endocrinol Metab. 2011;96:1727-36, http://dx.doi.org/10.1210/jc.2010-2784.

72. McClung MR, Boonen S, Törring O, Roux C, Rizzoli R, Bone HG, et al. Effect of denosumab treatment on the risk of fractures in subgroups of women with postmenopausal osteoporosis. J Bone Miner Res. 2011;27:211-8, http://dx.doi.org/10.1002/jbmr.536.

73. Bone HG, Wagman RB, Brandy M, Brown JP, Chapurlat R, Cummings $\mathrm{SR}$, et al. 10 years of denosumab treatment in postmenopausal women with osteoporosis: results from the phase 3 randomised FREEDOM trial and open-label extension. Lancet Diabetes Endocrinol. 2017;5:513-23, http://dx.doi.org/10.1016/s2213-8587(17)30138-9.

74. Palacios S, Kalouche-Khalil L, Rizzoli R, Zapalowski C, Resch H, Adachi $\mathrm{JD}$, et al. Treatment with denosumab reduces secondary fracture risk in women with postmenopausal osteoporosis. Climacteric. 2015;18:805-12, http://dx.doi.org/10.3109/13697137.2015.1045484.

75. Morizio P, Burkhart JI, Ozawa S. Denosumab: a unique perspective on adherence and cost-effectiveness compared with oral bisphosphonates in osteoporosis patients. Ann Pharmacother. 2018;52:1031-41, http://dx.doi.org/ $10.1177 / 1060028018768808$

76. Mori T, Crandall CJ, Ganz DA. Cost-effectiveness of denosumab versus oral alendronate for elderly osteoporotic women in Japan. Osteoporos Int. 2017;28:1733-44, http://dx.doi.org/10.1007/s00198-017-3940-4.

77. Silverman S, Agodoa I, Kruse M, Parthan A, Orwoll E. Denosumab for elderly men with osteoporosis: a cost-effectiveness analysis from the US Payer Perspective. J Osteoporos. 2015;2015:627631, http://dx.doi.org/ $10.1155 / 2015 / 627631$.

78. Darbá J, Kaskens L, Sorio F, Lothgren M. Cost-utility of denosumab for the treatment of postmenopausal osteoporosis in Spain. Clinicoecon Outcomes Res. 2015:7:105-17, http://dx.doi.org/10.2147/ceor.s78349.

79. Stolshek B, Kruse M, Yurgin N, Huang J, Ho P, Parthan W, et al. Costeffectiveness of denosumab vs. zoledronic acid in a population 75 years or older in the US. European Congress on Osteoporosis and Osteoarthritis (ESCEO13IOF): Poster Presentation Abstracts. Osteoporos Int. 2013;24 Suppl 1:S137-8, http://dx.doi.org/10.1007/s00198-013-2312-y.

80. Neer RM, Arnaud CD, Zanchetta JR, Prince R, Gaich GA, Reginster JY, et al. Effect of parathyroid hormone (1-34) on fractures and bone mineral density in postmenopausal women with osteoporosis. N Engl J Med. 2001;344:1434-41, http://dx.doi.org/10.1056/NEJM200105103441904.

81. McGarvey C, Coughlan T, O'Neill D. Ageism in studies on the management of osteoporosis. J Am Geriatr Soc. 2017;65:1566-8, http://dx.doi.org/ 10.1111 /jgs. 14840 .

82. Boonen S, Marin F, Mellstrom D, Xie L, Desaiah D, Krege JH, et al. Safety and efficacy of teriparatide in elderly women with established osteoporosis: bone anabolic therapy from a geriatric perspective. J Am Geriatr Soc. 2006;54:782-9, http://dx.doi.org/10.1111/j.1532-5415.2006.00695.x.

83. Marcus R, Wang O, Satterwhite J, Mitlak B. The skeletal response to teriparatide is largely independent of age, initial bone mineral density, and prevalent vertebral fractures in postmenopausal women with osteoporosis. J Bone Miner Res. 2003;18:18-23, http://dx.doi.org/10.1359/jbmr.2003.18.1.18.

84. Niimi R, Kono T, Nishihara A, Hasegawa M, Matsumine A, Kono T, et al. Usefulness of daily teriparatide treatment in elderly patients over 80 years of age. Osteoporos Int. 2016;27:1869-74, http://dx.doi.org/ 10.1007/s00198-015-3479-1.

85. Walsh JB, Lems WF, Karras D, Langdahl BL, Ljunggren O, Fahrleitner-Pammer A, et al. Effectiveness of Teriparatide in women over 75 years of age with severe osteoporosis: 36-month results from the European Forsteo Observational Study (EFOS). Calcif Tissue Int. 2012;90:373-83, http://dx.doi.org/ 10.1007/s00223-012-9590-9.

86. Aspenberg P, Malouf J, Tarantino U, García-Hernández PA, Corradini C, Overgaard $\mathrm{S}$, et al. Effects of teriparatide compared with risedronate on recovery after pertrochanteric hip fracture: results of a randomized, active-controlled, double-blind clinical trial at 26 weeks. J Bone Joint Surg Am. 2016;98:1868-78, http://dx.doi.org/10.2106/jbjs.15.01217.

87. Malouf-Sierra J, Tarantino U, García-Hernández PA, Corradini C, Overgaard S, Stepan JJ, et al. Effect of teriparatide or risedronate in elderly patients with a recent pertrochanteric hip fracture: final results of a 78-week randomized clinical trial. J Bone Miner Res. 2017;32:1040-51, http://dx.doi.org/10.1002/jbmr.3067.

88. Kendler DL, Marin F, Zerbini CAF, Russo LA, Greenspan SL, Zikan V, et al. Effects of teriparatide and risedronate on new fractures in post-menopausal women with severe osteoporosis (VERO): a multicentre, double-blind, doubledummy, randomised controlled trial. Lancet. 2018;391(10117):230-40, http://dx.doi.org/10.1016/s0140-6736(17)32137-2.

89. McClung MR, Geusens P, Miller PD, Zippel H, Bensen WG, Roux C, et al., Hip Intervention Program Study Group. Effect of risedronate on the risk of hip fracture in elderly women. N Engl J Med. 2001;344:333-40, http://dx.doi.org/10.1056/NEJM200102013440503.

90. Marco R, Caniego MD, Marcos G, Barreda D. Tratamiento de la osteoporosis postmenopáusica: a quién, cómo, cuánto. Boletín Farmacoterapéutico de Castilla La Mancha. Área de Farmacia, Comisiones de Farmacia y Terapéutica y del Uso Racional del Medicamento de las Gerencias de Área Integrada y de las Gerencias de Atención Especializada y Primaria de Toledo, editor. 2017;VXIII(1):1-10. Available from: http://sescam.castillalamancha.es/sites/sescam.castillalamancha.es/files/ documentos/farmacia/bft_1_2017.pdf [accessed 09.01.18].
91. National Institute for Health and Clinical Excellence (UK). Systematic reviews of clinical effectiveness prepared for the guideline osteoporosis: assessment of fracture risk and the prevention of osteoporotic fractures in individuals at high risk. National Collaborating Centre for Nursing and Supportive Care. Osteoporosis Evidence Review; 2008. Available from: https://www.nice.org.uk/guidance/cg146/documents/osteoporosis-evidencereviews2 [accessed 11.11.17].

92. Inderjeeth CA, Foo ACH, Lai MMY, Glendenning P. Efficacy and safety of pharmacological agents in managing osteoporosis in the old: review of the evidence. Bone. 2009;44:744-51, http://dx.doi.org/10.1016/j.bone.2008.12.003.

93. Boonen S, Black DM, Colon-Emeric CS, Eastell R, Magaziner JS, Eriksen EF, et al. Efficacy and safety of a once-yearly intravenous zoledronic acid $5 \mathrm{mg}$ for fracture prevention in elderly postmenopausal women with osteoporosis aged 75 and older. J Am Geriatr Soc. 2010;58:292-9, http://dx.doi.org/ $10.1111 / j .1532-5415.2009 .02673 . x$

94. Hiligsmann M, Evers SM, Sedrine WB, Kanis JA, Ramaekers B, ReginsterJY, et al. A systematic review of a costeffectiveness analyses of drugs for postmenopausal osteoporosis. PharmacoEconomics. 2014;33:205-24, http://dx.doi.org/10.1007/s40273-014-0231-1.

95. Curtis JR, Arora T, Matthews RS, Taylor A, Becker DJ, Colon-Emeric C, et al. Is withholding osteoporosis medication after fracture sometimes rational? A comparison of the risk for second fracture versus death. J Am Med Dir Assoc. 2010;11:584-91, http://dx.doi.org/10.1016/j.jamda.2009.12.004.

96. Huntjens KMB, van Geel TA, van den Bergh JP, van Helden S, Willems P, Winkens $B$, et al. Fracture liaison service: impact on subsequent nonvertebral fracture incidence and mortality. J Bone Joint Surg Am. 2014;96:e29, http://dx.doi.org/10.2106/jbjs.l.00223.

97. Nurmi-Luthje I, Sund R, Juntunen M, Luthje P. Post-hip fracture use of prescribed calcium plus vitamin d or vitamin d supplements and antiosteoporotic drugs is associated with lower mortality: a nationwide study in Finland. J Bone Miner Res. 2011;26:1845-53, http://dx.doi.org/10.1002/jbmr.375.

98. Lyles KW, Colón-Emeric CS, Magaziner JS, Adachi JD, Pieper CF, Mautalen C, et al. Zoledronic acid in reducing clinical fracture and mortality after hip fracture. $\mathrm{N}$ Engl J Med. 2007;357:1799-809, http://dx.doi.org/10.1056/nejmoa074941.

99. Beaupre LA, Morrish DW, Hanley DA, Maksymowych WP, Bell NR, Juby AG, et al. Oral bisphosphonates are associated with reduced mortality after hip fracture. Osteoporos Int. 2011;22:983-91, http://dx.doi.org/ 10.1007/s00198-010-1411-2.

100. Peng J, Liu Y, Chen L, Peng K, Xu Z, Zhang D, et al. Bisphosphonates can prevent recurrent hip fracture and reduce the mortality in osteoporotic patient with hip fracture: a meta-analysis. Pakistan J Med Sci. 2016;32:499-504, http://dx.doi.org/10.12669/pjms.322.9435.

101. Cameron ID, Chen JS, March LM, Simpson JM, Cumming RG, Seibel MJ, et al. Hip fracture causes excess mortality owing to cardiovascular and infectious disease in institutionalized older people: a prospective 5-year study. J Bone Miner Res. 2010;25:866-72, http://dx.doi.org/10.1359/jbmr.091029.

102. Bolland MJ, Grey AB, Gamble GD, Reid IR. Effect of osteoporosis treatment on mortality: a meta-analysis. J Clin Endocrinol Metab. 2010;95:1174-81, http://dx.doi.org/10.1210/jc.2009-0852.

103. Yun H, Delzell E, Saag KG, Kilgore ML, Morrisey MA, Muntner P, et al. Fractures and mortality in relation to different osteoporosis treatments. Clin Exp Rheumatol. 2015;33:302-9. PMCID: PMC5733785.

104. Cengiz Ö, Polat G, Karademir G, Tunç OD, Erdil M, Tuncay I, et al. Effects of zoledronate on mortality and morbidity after surgical treatment of hip fractures. Adv Orthop. 2016;2016:1-7, http://dx.doi.org/10.1155/2016/3703482.

105. Eriksen EF, Lyles KW, Colón-Emeric CS, Pieper CF, Magaziner JS, Adachi JD, et al. Antifracture efficacy and reduction of mortality in relation to timing of the first dose of zoledronic acid after hip fracture. J Bone Miner Res. 2009;24:1308-13, http://dx.doi.org/10.1359/jbmr.090209.

106. Center JR, Bliuc D, Nguyen ND, Nguyen TV, Eisman JA. Osteoporosis medication and reduced mortality risk in elderly women and men. J Clin Endocrinol Metab. 2011;96:1006-14, http://dx.doi.org/10.1210/jc.2010-2730.

107. Colón-Emeric CS, Mesenbrink P, Lyles KW, Pieper CF, Boonen S, Delmas $\mathrm{P}$, et al. Potential mediators of the mortality reduction with zoledronic acid after hip fracture. J Bone Miner Res. 2010;25:91-7, http://dx.doi.org/ 10.1359/jbmr.090704.

108. Kang JH, Keller JJ, Lin HC. Bisphosphonates reduced the risk of acute myocardial infarction: a 2-year follow-up study. Osteoporos Int. 2013;24:271-7. http://dx.doi.org/10.1007/s00198-012-2213-5.

109. Sambrook PN, Cameron ID, Chen JS, March LM, Simpson JM, Cumming RG et al. Oral bisphosphonates are associated with reduced mortality in frail older people: a prospective five-year study. Osteoporos Int. 2011;22:2551-6, http://dx.doi.org/10.1007/s00198-010-1444-6.

110. Lu PY, Hsieh CF, Tsai YW, Huang WF. Alendronate and raloxifene use related to cardiovascular diseases: differentiation by different dosing regimens of alendronate. Clin Ther. 2011;33:1173-9, http://dx.doi.org/ 10.1016/j.clinthera.2011.07.012.

111. Ugur Ural A, Avcu F, Ozturk K. Bisphosphonates may retrieve endothelial function in vascular diseases similar to statins' effects. Eur J Haematol. 2008;81:77-8, http://dx.doi.org/10.1111/j.1600-0609.2008.01068.x.

112. Azagra R, Roca G, Encabo G, Prieto D, Aguyé A, Zwart M. Prediction of absolute risk of fragility fracture at 10 years in a Spanish population: validation of the WHO FRAX TM tool in Spain. BMC Musculoskelet Disord. 2011;12:30 http://dx.doi.org/10.1186/1471-2474-12-30. 
113. Bonafede M, Shi N, Barron R, Li X, Crittenden DB, Chandler D. Predicting imminent risk for fracture in patients aged 50 or older with osteoporosis using US claim data. Arch Osteoporos. 2016;11:26, http://dx.doi.org/10.1007/s11657-016-0280-5.

114. Johansson H, Siggeirsdottir K, Harvey NC, Odén A, Gudnason V, McCloskey E, et al. Imminent risk of fracture after fracture. Osteoporos Int. 2017;28:775-80, http://dx.doi.org/10.1007/s00198-016-3868-0.

115. Black DM, Delmas PD, Eastell R, Reid IR, Boonen S, Cauley JA, et al. Once-yearly zoledronic acid for treatment of postmenopausal osteoporosis. N Engl J Med. 2007;356:1809-22, http://dx.doi.org/10.1056/NEJMoa067312.

116. Liberman D, Cheung A. A practical approach to osteoporosis management in the geriatric population. Can Geriatr J. 2015;18:29-34, http://dx.doi.org/10.5770/cgj.18.129.

117. Reyes C, Tebe C, Martínez-Laguna D, Ali MS, Soria-Castro A, Carbonell $C$, et al. One and two-year persistence with different anti-osteoporosis medications: a retrospective cohort study. Osteop Int. 2017;28:2997-3004, http://dx.doi.org/10.1007/s00198-017-4144-7.

118. Alonso García N. Predicción de mortalidad y reingreso tras fractura de cadera por fragilidad en ancianos. Tesis Doctoral. Salamanca: Universidad de Salamanca; 2016. p. 304. http://hdl.handle.net/10366/132891

119. Hu F, Jiang C, Shen J, Tang P, Wang Y. Preoperative predictors for mortality following hip fracture surgery: a systematic review and meta-analysis. Injury. 2012;43:676-85, http://dx.doi.org/10.1016/j.injury.2011.05.017.

120. Smith T, Pelpola K, Ball M, Ong A, Myint PK. Pre-operative indicators for mortality following hip fracture surgery: a systematic review and meta-analysis. Age Ageing. 2014;43:464-71, http://dx.doi.org/10.1093/ageing/afu065.

121. Karres J, Heesakkers NA, Ultee JM, Vrouenraets BC. Predicting 30-day mortality following hip fracture surgery: evaluation of six risk prediction models. Injury. 2015;46:371-7, http://dx.doi.org/10.1016/j.injury.2014.11.004.

122. Marufu TC, Mannings A, Moppett IK. Risk scoring models for predicting peri-operative morbidity and mortality in people with fragility hip fractures: qualitative systematic review. Injury. 2015;46:2325-34, http://dx.doi.org/10.1016/j.injury.2015.10.025.

123. Maxwell MJ, Moran CG, Moppett IK. Development and validation of a preoperative scoring system to predict 30 day mortality in patients undergoing hip fracture surgery. $\mathrm{Br} J$ Anaesth. 2008;101:511-7, http://dx.doi.org/10.1093/bja/aen236.

124. Rushton PRP, Reed MR, Pratt RK. Independent validation of the Nottingham Hip Fracture Score and identification of regional variation in patient risk within England. Bone Joint J. 2015;97-B:100-3, http://dx.doi.org/10.1302/0301-620X.97B1.34670.

125. Moppett IK, Parker M, Griffiths R, Bowers T, White SM, Moran CG. Nottingham Hip Fracture Score: longitudinal and multi-assessment. $\mathrm{Br} \mathrm{J}$ Anaesth. 2012;109:546-50, http://dx.doi.org/10.1093/bja/aes187.

126. Marufu TC, White SM, Griffiths R, Moonesinghe SR, Moppett IK. Prediction of 30-day mortality after hip fracture surgery by the Nottingham Hip Fracture Score and the Surgical Outcome Risk Tool. Anaesthesia. 2016;71:515-21, http://dx.doi.org/10.1111/anae.13418.

127. Wiles MD, Moran CG, Sahota O, Moppett IK. Nottingham Hip Fracture Score as a predictor of one year mortality in patients undergoing surgical repair of fractured neck of femur. Br J Anaesth. 2011;106:501-4, http://dx.doi.org/10.1093/bja/aeq405.

128. Bardales Y, González JI, Abizanda P, Alarcón MT. Guías clínicas de fractura de cadera. Comparación de sus principales recomendaciones. Rev Esp Geriatr Gerontol. 2012;47:220-7, http://dx.doi.org/10.1016/j.regg.2012.02.014.

129. Alarcón T, González JI. Atención integral al anciano con fractura de cadera. In: Abidanza P. Rodríguez L, editors. Tratado de Medicina Geriátrica. Fundamentos de la atención sanitaria a los mayores. Elsevier; 2015. p. 635-44.

130. Vidan M, Serra JA, Moreno C, Riquelme G, Ortiz J. Efficacy of a comprehensive geriatric intervention in older patients hospitalized for hip fracture: a randomized, controlled trial. J Am Geriatr Soc. 2005;53:1476-82, http://dx.doi.org/10.1111/j.1532-5415.2005.53466.x.

131. Chong CPW, Savige JA, Lim WK. Medical problems in hip fracture patients. Arch Orthop Trauma Surg. 2010;130:1355-61, http://dx.doi.org/ 10.1007/s00402-009-1038-y.
132. Fisher AA, Davis MW, Rubenach SE, Sivakumaran S, Smith PN, Budge MM. Outcomes for older patients with hip fractures: the impact of orthopedic and geriatric medicine cocare. J Orthop Trauma. 2006;20:172-8, http://dx.doi.org/10.1097/01.bot.0000202220.88855.16, discussion 179-80.

133. Gregersen M, Mørch MM, Hougaard K, Damsgaard EM. Geriatric intervention in elderly patients with hip fracture in an orthopedic ward. J Inj Violence Res. 2012;4:45-51, http://dx.doi.org/10.5249/jivr.v4i2.96.

134. Sánchez-Hernández N, Sáez-López P, Paniagua-Tejo S, Valverde-García JA. Results following the implementation of a clinical pathway in the process of care to elderly patients with osteoporotic hip fracture in a second level hospital. Rev Esp Cir Ortop Traumatol. 2015;60:1-11, http://dx.doi.org/10.1016/j.recot.2015.08.001.

135. Sáez P, González-Montalvo JI, Alarcón T, Madruga F, Bárcena A. Optimización del tratamiento médico en pacientes geriátricos con fractura de cadera. Influencia del equipo consultor geriátrico. Rev Esp Geriatr Gerontol. 2006;41:85-91, http://dx.doi.org/10.1016/S0211-139X(06)72931-6.

136. Kates SL. Hip fracture programs: are they effective? Injury. 2016;47:S25-7, http://dx.doi.org/10.1016/S0020-1383(16)30006-7.

137. Hawley S, Javaid MK, Prieto-Alhambra D, Lippett J, Sheard S, Arden NK, et al. Clinical effectiveness of orthogeriatric and fracture liaison service models of care for hip fracture patients: population-based longitudinal study. Age Ageing. 2016;45:236-42, http://dx.doi.org/10.1093/ageing/afv204.

138. Sabharwal S, Wilson H. Orthogeriatrics in the management of frail older patients with a fragility fracture. Osteoporos Int. 2015;26:2387-99, http://dx.doi.org/10.1007/s00198-015-3166-2.

139. Zeltzer J, Mitchell RJ, Toson B, Harris IA, Ahmad L, Close J. Orthogeriatric services associated with lower 30-day mortality for older patients who undergo surgery for hip fracture. Med J Aust. 2014;201:409-11, http://dx.doi.org/10.5694/mja14.00055.

140. Boddaert J, Cohen-Bittan J, Khiami F, Le Manach Y, Raux M, Beinis JY, et al. Postoperative admission to a dedicated geriatric unit decrease mortality in elderly patients with hip fracture. PLOS ONE. 2014;9:1-10, http://dx.doi.org/10.1371/journal.pone.0083795.

141. Barone A, Giusti A, Pizzonia M, Razzano M, Palummeri E, Pioli G. A comprehensive geriatric intervention reduces short- and long-term mortality in older people with hip fracture. J Am Geriatr Soc. 2006;54:711-2, http://dx.doi.org/10.1111/j.1532-5415.2006.00668_1.x.

142. Grigoryan KV, Javedan H, Rudolph JL. Orthogeriatric care models and outcomes in hip fracture patients: a systematic review and meta-analysis. J Orthop Trauma. 2014;28:e49-55, http://dx.doi.org/10.1097/BOT.0b013e3182a5a045.

143. Kristensen PK, Thillemann TM, Søballe K, Johnsen SP. Can improved quality of care explain the success of orthogeriatric units? A population-based cohort study. Age Ageing. 2016;45:66-71, http://dx.doi.org/10.1093/ageing/afv155.

144. Judge Q Javaid MK, Leal J, Hawley S, Drew S, Sheard S, et al. Models of care for delivery of secondary fracture prevention after hip fracture: a health service cost, clinical outcomes and cost-effectiveness study within a region of England. Health Serv Deliv Res. 2016;4, http://dx.doi.org/10.3310/hsdr04280.

145. Blain H, Masud T, Dargent-Molina P, Martín FC, Rosendahl E. A comprehensive fracture prevention strategy in older adults: the European Union Geriatric Medicine Society (EUGMS) statement. Aging Clin Exp Res. 2016;28:797-803, http://dx.doi.org/10.1007/s40520-016-0588-4.

146. Sanderson J, Martyn-St James M, Stevens J, Goka E, Wong R, Campbell F, et al. Clinical effectiveness of bisphosphonates for the prevention of fragility fractures: a systematic review and network meta-analysis. Bone. 2016;89:52-8 http://dx.doi.org/10.1016/j.bone.2016.05.013.

147. Davis S, Martyn-St James M, Sanderson J, Stevens J, Goka E, Rawdin A et al. A systematic review and economic evaluation of bisphosphonates for the prevention of fragility fractures. Health Technol Assess. 2016;20:1-406, http://dx.doi.org/10.3310/hta20780.

148. Zhou J, Ma X, Wang T, Zhai S. Comparative efficacy of bisphosphonates in short-term fracture prevention for primary osteoporosis: a systematic review with network meta-analyses. Osteoporos Int. 2016;27:3289-300 http://dx.doi.org/10.1007/s00198-016-3654-z. 